\title{
Assessing Volcanic Hazard and Exposure at Obscure Volcanic Fields: A Case Study from the Bolaven Volcanic Field, Laos
}

\author{
Andrea Verolino ( $\square$ andrea_verolino@hotmail.it) \\ Nanyang Technological University \\ Susanna F. Jenkins \\ Nanyang Technological University \\ Kerry Sieh \\ Nanyang Technological University \\ Jason S. Herrin \\ Nanyang Technological University \\ Dayana Schonwalder-Angel \\ Nanyang Technological University \\ Vanpheng Sihavong \\ Department of Geology and Mines \\ Jee Hon Oh \\ Nanyang Technological University
}

\section{Research}

Keywords: Bolaven Volcanic Field, Vent spatial density estimation, MOLASSES, Hazard, Exposure, Recurrence interval

Posted Date: October 11th, 2021

DOI: https://doi.org/10.21203/rs.3.rs-952442/v1

License: (c) (1) This work is licensed under a Creative Commons Attribution 4.0 International License. Read Full License 


\title{
Assessing volcanic hazard and exposure at obscure volcanic fields: A case study from the Bolaven
}

\section{Volcanic Field, Laos}

a Andrea Verolino, a,b Susanna F. Jenkins, a,b Kerry Sieh, a Jason S. Herrin, a Dayana Schonwalder-Angel, c Vanpheng Sihavong,

\author{
bJee Hon Oh
}

aEarth Observatory of Singapore, Nanyang Technological University, Singapore

${ }^{b}$ Asian School of Environment, Nanyang Technological University, Singapore

'Department of Geology and Mines, Ministry of Energy and Mines, Vientiane, Lao People's Democratic Republic

Correspondence: Dr. Andrea Verolino- andrea verolino@hotmail.it

Key words: Bolaven Volcanic Field, Vent spatial density estimation, MOLASSES, Hazard, Exposure, Recurrence interval

\section{Abstract}

Southeast Asia hosts a large number of active and well-studied volcanoes, the majority of which are located in Indonesia and the Philippines. Northern Southeast Asia (Myanmar, Cambodia, Laos, Thailand and Vietnam) also hosts volcanoes that for several reasons (post-World War II conflicts, poor accessibility due to dense vegetation, no known historical activity) have been little studied. Systematic assessments of the threat these volcanoes pose to resident populations do not exist, despite evidence of numerous eruptions through the late Pleistocene and likely even during the Holocene. A recent study that inferred the location of the Australasian meteorite impact (which produced the largest known tektite strewn field on Earth) beneath the Bolaven Volcanic Field in southern Laos provided a wealth of data for that volcanic field, in particular, mapping of vents and flows, and their absolute ages. Building upon this foundation, we used the Bolaven Volcanic Field as a case study for assessing the potential exposure of populations and infrastructure to lava flows during future eruptions there. Our study uses remote sensing of past flows, lava-flow simulations and open-access exposure data, to assess hazards and exposure. Our results show that future vents are most likely to occur in a N-S band atop the Bolaven Plateau, with some flows channelled into canyons that spill down the plateau flanks onto lower plains that support more populated areas such as the provincial centre, Pakse. Our exposure assessment suggests that around 300,000 people could experience socio-economic impacts from future eruptions. The largest impacts would be on two of the main economic sectors in the region, agriculture and hydropower. The potential also exists for life-threatening explosions from interactions between magma and surface waters, which are abundant in the region. We estimate an Average Recurrence Interval of approximately 10,400 years. 


\section{Introduction}

Southern Vietnam, northern Cambodia, eastern Thailand and southern Laos host many LateCenozoic basaltic volcanic fields, scattered over about 50,000 km² (Fig. 1). Few studies of these fields exist, and those that do focus mainly on regional tectonics and possible magmatic sources. Barr and Macdonald (1981) argued that these basalts comprise a large continental basaltic province, which includes the submarine volcano lle des Cendres, $\sim 120 \mathrm{~km}$ south-east of Vietnam, which formed several cones when it last erupted in 1923. They note, however, that the temporal and geochemical variability of the region's basalts do not show any obvious geographical pattern. The eruptive products range from alkaline to tholeiitic to olivine basalts and span ages from about $0.5 \mathrm{Ma}$ to $12 \mathrm{Ma}$. They hypothesize that this unpatterned variability reflects the presence of discrete magma sources interacting at various times, contributing magmas from various degrees of partial melting in a region of complex tectonic interactions. Whitford-Stark (1987) conducted a similar study to characterize the basalts across a much larger swath of mainland Asia and including this region. They characterized the distribution, age, geochemistry and origin of the volcanics. These authors also list a few potentially historically active volcanoes, including Mount Popa, Myanmar, which last erupted in 442 BCE). Both works highlighted the presence of young lava flows and well preserved scoria cones and crater lakes. The young (and even historical) ages of large lava flows encouraged us to conduct a more-focused study on the hazards represented by, exposures to, and risks from these volcanoes.

There are several reasons why such focused studies have not taken place previously. These include 1) the dangers of field work during and subsequent to the conflicts of the second half of the $20^{\text {th }}$ century, including the presence of still-unexploded ordnance; 2) the limited access due to dense tropical vegetation, as well as poor exposures; and 3) the scant historical eruptions, compared to the abundant historical eruptions along the volcanic arcs of Indonesia and The Philippines. Thus, the potential for future eruptions of these volcanic fields to affect growing and thriving populations, agriculture and tourism is under-appreciated and unknown.

For this study, we take advantage of a recent and significant increase in knowledge about one of the volcanic fields in northern SE Asia, the Bolaven Volcanic Field (BVF) in southern Laos (Fig. 1). Its broad summit occupies and its flows spill down the flanks of the western and northern parts of the Bolaven plateau, which is underlain by Mesozoic fluvial/lacustrine mudstones and sandstones. A 7year project on the Bolaven Plateau combined geological, petrological, geochemical and geophysical studies to identify a $17 \mathrm{~km}$ by $13 \mathrm{~km} \sim 790 \mathrm{ka}$ impact crater related to the tektites of the Australasian strewn field (Sieh et al., 2019). The crater lies wholly buried beneath the summit of the BVF, covered by post-impact lavas. In their quest to identify the crater location, Sieh et al. constructed a detailed geological map of the BVF, which included lava flows and scoria cones, and determined ${ }^{40} \mathrm{Ar}-{ }^{39} \mathrm{Ar}$ dates 

for lava flows from 37 locations. We utilize these data and additional field data and 30 additional geochronological dates to provide this first volcanic hazard and exposure assessment for the region.

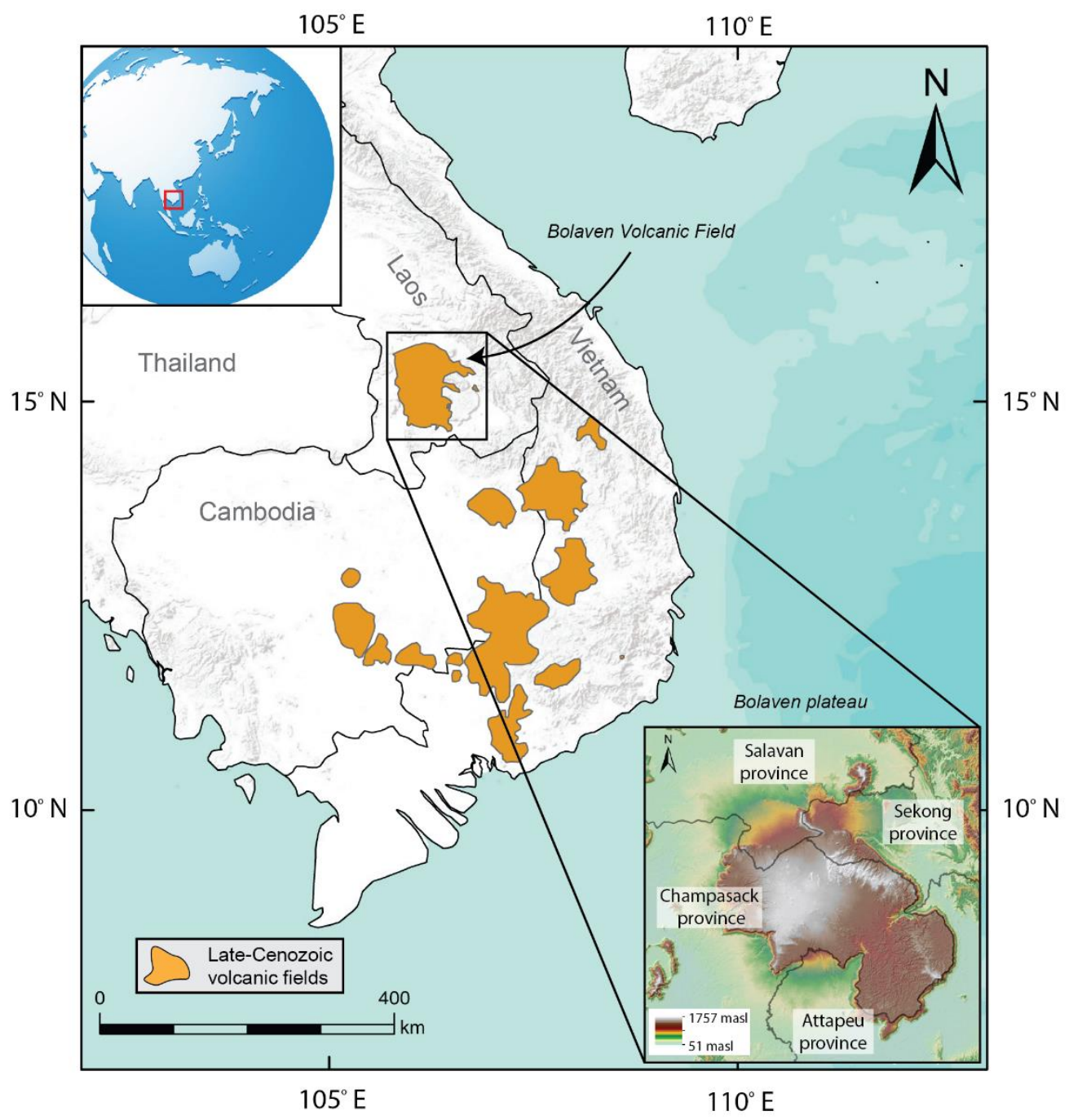

Fig. 1. Late Cenozoic volcanic fields in northern Southeast Asia. The Bolaven Volcanic Field is the northernmost of these fields, in southern Laos. The inset shows the Bolaven plateau and the Laotian provinces within which it resides.

Volcanic hazard assessments take into account spatial and/or temporal information from past activity of a volcano or volcanic field to forecast likely future activity (e.g. Cappello et al., 2012; Connor et al., 2012; Gallant et al., 2018). By coupling information on the hazard with that on exposure (e.g. the number and distribution of people and infrastructure within the affected area), we can make an estimate of the range of potential consequences from a future eruption (e.g. Barsotti et al., 2018; Freire et al., 2019; Jiménez et al., 2019). Such estimates support local authorities in characterising and preparing for future volcanic crises (e.g. Orsi et al., 2004; Felpeto et al., 2007; Bevilacqua et al., 2015; Jiménez et al., 2020). In most efforts, geoscientists have conducted volcanic hazard assessments on 
well-studied and easily accessible volcanoes. The BVF is neither well-studied nor easily accessible. Here we utilize a combination of field, remote-sensing, and numerical-modelling techniques that can be applied to other understudied, volcanic fields with difficult access.

The primary hazard associated with the BVF is lava flows. Previous studies that considered exposure to lava flows (e.g. Bonne et al., 2008; Bisson et al., 2009) have focused on currently active volcanoes. Deligne et al. (2017) and Hayes et al. (2021) assessed the impact on urban areas in the event of an eruption within New Zealand's historically dormant Auckland Volcanic Field (AVF). They constructed a multi-hazard scenario, with lava being only one of the hazards.

The BVF has no historical eruptive record. It is clear, however, that there are key assets that could be exposed to future lava flows. The potential infrastructure damage and economic loss from an eruption of the BVF may be significant. A quantitative assessment of exposure to the BVF could help Laotian communities and governments and their partners in planning for future volcanic crises. The national government recently requested such an assessment as part of a geohazards collaboration between the government of Laos and the Earth Observatory of Singapore, through the CCOP (the SE Asian association of geological-agency heads), in 2019.

Our assessment consists of four parts: i) Identification of vents and lava flows younger than (or indistinguishable in age from ) the meteorite impact ( $790 \mathrm{ka}$ - present); ii) Spatial-density analysis of volcanic vents to inform future vent opening location probability; iii) Probabilistic modelling of lava flow inundation using MOLASSES (Modular Lava Simulation Software for Earth Sciences) from Gallant et al. (2018); and iv) Exposure assessment by combining the flow inundation map with population, infrastructure, and land cover data.

Another potential hazard for the BVF is represented by phreatomagmatic eruptions, given the large amount of water available in this region. These eruptions can occur through interaction between rising magma and external water (surface or groundwater) or between moving lava and water-saturated sediments.

Finally, we estimate a maximum BVF Average Recurrence Interval (ARI) for eruptions, based on the geological and geochronological information available.

\section{Geographic and socio-economic aspects of the Bolaven plateau and surroundings}

The Bolaven plateau extends over about $6000 \mathrm{~km}^{2}$ in the southern portion of the Mekong river basin, in southern Laos (Fig. 1). Champasack province covers the majority of the plateau and shares its northern border with Salavan and Xekong provinces and its southern border with Attapeu province. Most of the plateau has low relief, and summit elevations range between approximately 1000 and 
1350 masl. The unique combination of gentle topography, temperature, rainfall, solar radiation, and fertility of the basaltic soils makes the Bolaven plateau the most ideal place for coffee production in Laos (Tulet, 2007; Toro, 2012). Rubber, tea, cardamom and corn are also cultivated in the region, but to a lesser degree (Delang et al., 2013). Agriculture is the primary source of income for residents of the plateau and represents about 15\% of the nation's GDP (Delang et al., 2013; Applegate, 2016; World Bank, 2019).

Hydroelectric power generation is another important sector of Laos' economy. It accounts for $~ 85 \%$ of power production and supply in Laos (Department of Energy Policy and Planning, and Ministry of Energy and Mines, 2020). The Bolaven plateau has particularly favourable conditions for hydropower production, for the presence of large rivers and elevation gain. About $10 \%$ of Laos' operational dams are on the plateau (Open Development Laos, 2016). Of relevance to the aims of our study is the sudden failure of one dam on the southern portion of the plateau, which occurred in 2018 , causing floods and fatalities (Latrubesse et al., 2020). This study from Latrubesse and co-authors highlights the general difficulties in this region in assessing potential hazards, which may be indeed common.

Pakse, the largest city and capital of Champasak province lies on the east bank of the Mekong River, about $15 \mathrm{~km}$ from the western edge of the plateau. Smaller cities in the area are Paksong, which sits atop the plateau near the summit of the BVF, and Salavan, about $30 \mathrm{~km}$ north of the plateau, on the Xedon River, a tributary of the Mekong (Fig. 2). Numerous villages dot the volcanic landscape. All told, the total population living on and around the plateau is nearly 700,000 (WorldPop, 2020). Pakse is an important commercial and transport hub connecting Laos with neighbouring Vietnam, Thailand and Cambodia, and is also a major tourism centre. Paksong and Salavan are key assets for the production and export of coffee, but are also growing centers for tourists interested in exploration of historical and natural sites. Both tourism and agriculture can be impacted by natural hazards. According to a recent study (Japan International Cooperation Agency, 2015), Laos experienced, between 1983 and 2012, floods, cyclones, landslides and earthquakes, but only floods and cyclones caused significant damage. They define a hazard as "significant" when it causes damage $>1 \%$ of GDP and deaths $>100$. Surprisingly, the report states that there are no volcanoes in Laos. A general lack of awareness of volcanic hazard may, in fact, explain the lack of national volcanic hazard monitoring and data. While there are several national agencies (e.g. National Disaster Management Office, Water Resources and Environment Agency, Department of Meteorology and Hydrology) in charge of response to floods, cyclones, landslides and earthquakes, there is some ambiguity concerning response to volcanic eruptions. We are keen to help remedy this situation by providing quantitative information that could help communities and local and national authorities improve their ability to respond to future volcanic activity. 


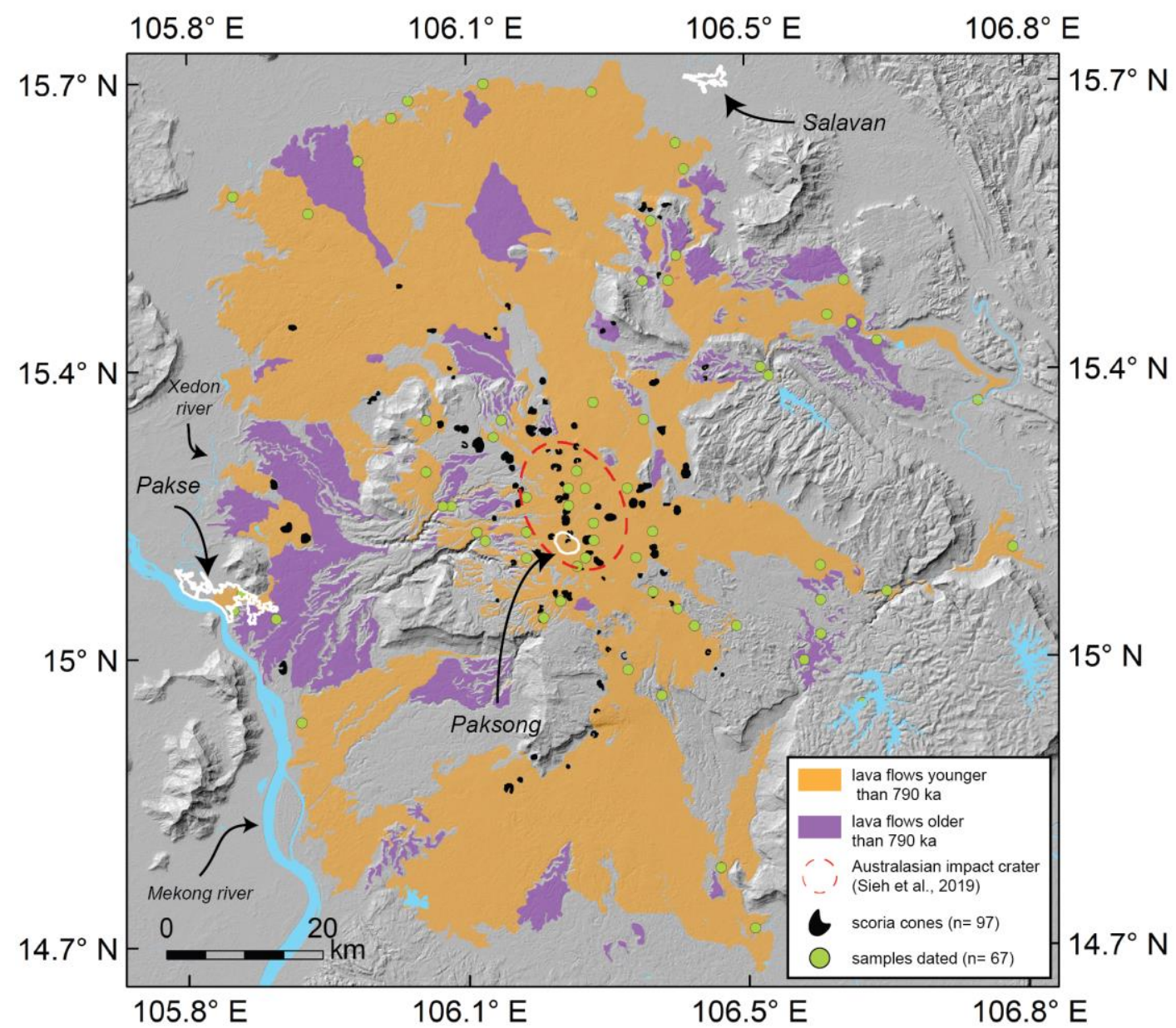

Fig. 2. Simplified geological map of the BVF. Volcanic units younger (orange) than the inferred Australasian impact crater cover the majority of the field, likely burying most older units (purple where exposed). Main cities are outlined in white.

\section{Geology of the Bolaven Volcanic Field}

The BVF consists of basaltic lavas that have erupted throughout the past 16 Ma (Sieh et al., 2019), through thick flat-lying Mesozoic non-marine clastic sedimentary rocks. Its summit lies on the western portion of the plateau, and flows have spilled over its northern, western, eastern and southern flanks. The flows have spread over about $5000 \mathrm{~km}^{2}$ (Fig. 2). Most of the flows are tholeiitic in composition, but many are alkali basalt. Many flows are $<100 \mathrm{ka}$ old, and the youngest flow complex may be barely prehistoric, judging by the immaturity of virgin forests that cover it. That youngest flow complex, which erupted from a source on the plateau about $13 \mathrm{~km}$ south of Paksong, includes flows that extend southward about $45 \mathrm{~km}$, over the flank of the plateau and onto the adjacent plain. The volume of the BVF is $\sim 900 \mathrm{~km}^{3}$ and nearly 100 scoria cones are visible on its surface. Thickness of the BVF ranges from about $350 \mathrm{~m}$ at its summit to a few meters on its perimeters.

Other studies of the BVF have focused on mineral resources (e.g. Sanematsu et al., 2011; Phommakaysone, 2012; Long et al., 2019). The Japan International Cooperation Agency (2008) created 
a geological map of the Bolaven plateau to assist the Lao PDR Ministry of Energy and Mines in identifying zones with high potential for mineral extraction. The JICA report includes geochemical and petrological data from the BVF lavas (pyroxene basalts, andesites, olivine basalts, and alkali basalts) and twelve K-Ar/Ar-Ar dates (Neogene to late Quaternary). Sanematsu et al. (2011) investigated laterite formation on the BVF basalts. Their geochemical and chronological work led them to divide the basalts into three groups (small-volume alkali basalts, 15.7 Ma; large-volume olivine tholeiites, 1.2 $\mathrm{Ma}$; and quartz and olivine tholeiites, younger than $0.5 \pm 0.2 \mathrm{Ma}$ ). Their five ${ }^{40} \mathrm{Ar}-{ }^{39} \mathrm{Ar}$ dates are in agreement with Sieh et al. (2019), who provide a far more extensive dataset for the BVF that sheds much more light on its complex volcanic history. In particular, the young ages found for some of the flows ( $<40 \mathrm{ka}$ ), besides the amount of data recently made available, motivated us to investigate the BVF further, with a focus on the more recent volcanic history for the first time. An even more extensive dataset on the BVF basalts' geochemistry and petrology is in preparation (Herrin et al., In prep.).

\section{Methods}

\subsection{Mapping techniques}

We present an updated version of the BVF geological map published by Sieh et al. (2019) (simplified map in Fig. 2 and detailed map in a data repository at https://researchdata.ntu.edu.sg/privateurl.xhtml?token=605d1696-0a8d-47cf-afeb-5e18398a6ef2). The updated map includes new field observations, 30 new ${ }^{40} \mathrm{Ar}-{ }^{39} \mathrm{Ar}$ dates of lava flows, and new interpretations based on digital imagery from (CGoogle Earth Pro and a geospatial analysis using Esri® ArcMap 10.7.1 (Fig. 3). Field observations included: 1) The use of vegetation as a proxy to determine the relative age of the very youngest flows (i.e. an immature virgin forest implies a very young age), before performing ${ }^{40} \mathrm{Ar}-{ }^{39} \mathrm{Ar}$ dating; 2) Geomorphological evidence (e.g. differential erosion of neighbouring flows indicating different relative age, or evidence of rivers displaced by lava flows); and 3) Different macro-scale flow textures (e.g. colour, relative abundance of minerals and mineral type, level of weathering). Satellite imagery was mostly used in combination with field observations. ArcMap 10.7.1 was used to create topographic contours from a Digital Elevation Model (Shuttle Radar Topography Mission, 30-m resolution), in order to identify, where possible, different flows (even within the same flow complex) and topographic features associated with them (e.g. scoria cones). Scoria cones were mapped based on (i) height (at least a few tens of meters high), (ii) morphology, which also provided clues on their relative age (i.e. conical, horseshoe-like, flat-topped, with the first and the last being relatively younger and older respectively), and (iii) location respect to the nearby lava flow(s) (surrounded or incorporated by/in the nearby flow(s), to define if they were older or the 
same age of that flow). Besides scoria cones, other positive-relief topographical features were present, and were mapped as "mounds". A common characteristic of these mounds is the relatively low H/W ratio (height less than $10 \mathrm{~m}$, occasionally up to $30 \mathrm{~m}$; width from a few hundred meters up to a few kilometres). We interpret them as lava flow structures (e.g. tumuli, lava rises, hornitos, squeeze-ups; e.g. Nemeth et al., 2003; Murcia et al., 2014; Mishra et al., 2019), but we do not exclude the possibility that some may represent volcanic vents, and/or artefacts created by tall, dense vegetation during the generation of the DEM. Also some volcanic fissures were inferred from the SRTM, based on

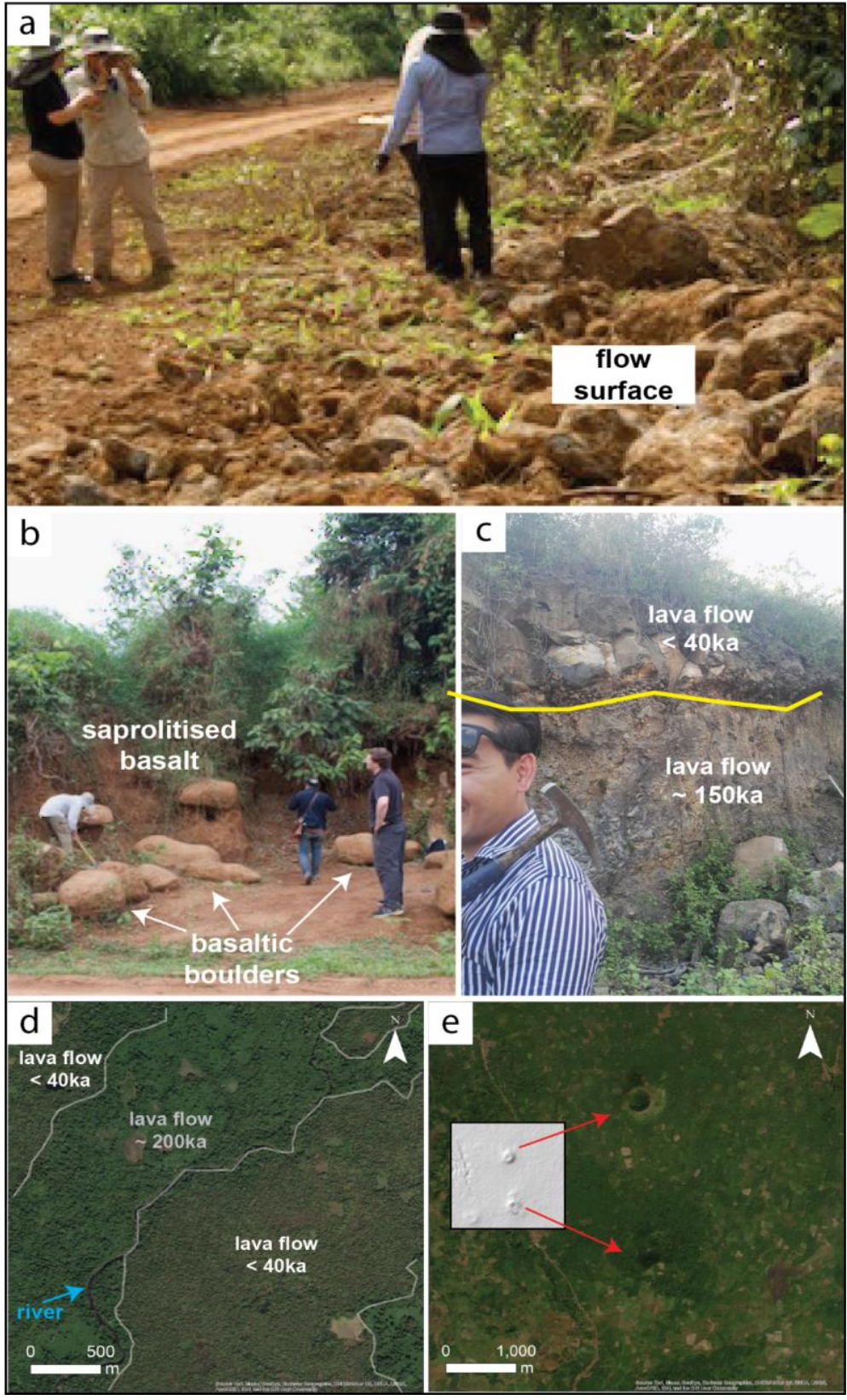


Fig. 3. Representative examples of lava flows and scoria cones found on the BVF. Approximate ages are provided, based on absolute dating at nearby locations. a) 34 ka old lava flow (location: $22 \mathrm{~km} \mathrm{NW}$ of Paksong); b) Basalt boulders $215 \pm 41 \mathrm{ka}$ old, surrounded by saprolitised basalt (location: $\sim 18 \mathrm{~km}$ ENE of Paksong); c) Contact between a flow younger than $40 \mathrm{ka}$ (top) and an older flow, $\sim 150 \mathrm{ka}$ (bottom) (location: $\sim 16 \mathrm{~km} \mathrm{~S}$ of Paksong); d) Satellite image of a relatively young lava flow (<40ka) next to an older one ( $200 \mathrm{ka}$ ), separated by a river (likely displaced by the younger flow). Also note the different colour in vegetation, with the greener vegetation (more mature) for the older flow (location: $30 \mathrm{~km} \mathrm{~S}$ of Paksong); e) Satellite image (DEM in the inset) of two uneroded, young scoria cones of the young North Flow Complex.

\subsection{Kernel Density Estimation: definition, use, and applications in volcanology}

A Kernel Density Estimation (KDE) is a nonparametric statistical method used to represent the distribution of physical features (points or lines) through space. Over the last decade It has been widely used in geoscience (e.g. Ramanna and Dodagoudar, 2012; Colkesen et al., 2016). For volcanic hazard assessments, the KDE method is used to predict the location of future vents, based on the location of vents formed in the past (Connor et al., 2012; Bartolini et al., 2013; Gallant et al., 2018). This process assumes that new vents will form through the same magmatic/tectonic mechanisms that formed the old vents (Connor et al., 2019).

Elements of a KDE are the kernel function and the bandwidth. The kernel function defines the probability of future vent formation at locations within a certain region, and can be of different statistical types (e.g. Gaussian, Cauchy, Epanechnikov, Triangular, Uniform, Triweight, Quartic); the bandwidth is the search radius within which the density is calculated. The latter, in particular, is more sensitive to the resulting output relative to the type of kernel function (Martin et al., 2004), and therefore requires careful selection. We performed the KDE with ArcMap 10.7.1, which uses a Quartic kernel function (Silverman, 1998) and provides a default bandwidth (defined as search radius in the software) of $\sim 7.4 \mathrm{~km}$, computed specifically for the input dataset (distribution and number of scoria cones across the BVF) using a spatial variant of Silverman's Rule of Thumb (Silverman, 1998). This method, compared to more classic spatial density estimations, is weighted for spatial outliers, which pertains to some vents on the BVF (Fig. 4).

As input data for the KDE on the BVF, we selected vents based upon two main criteria: 1) Our confidence that the source is indeed a vent; and 2) The vent age is younger or equal to $790 \mathrm{ka}$ (the age of the Australasian impact crater). For the first criterion, we binned eruptive vents on the BVF into three types: Scoria cones, mounds and fissures. Only scoria cones $(n=76)$ were considered for the estimation of the vent spatial distribution on the BVF. We ignored the many low-relief mounds and fissures, because we know from ground-truthing some of these that the dense and tall vegetation common in the region is the cause of some of these features in the DEM. Moreover, the relative vertical accuracy of the SRTM is around 6-m at these latitudes (Brown et al., 2005), about the same as the height of these features. We constrained vents to those younger than the impact crater age as a 
reference for the volcanic hazard assessment of the BVF for two main reasons: i) The Australasian meteorite impact represented an important event in the volcanic history of the Bolaven Plateau. Although volcanism began long before the impact, there are hints that the event may have affected the rate of melt production (Sieh et al., 2019), as has been inferred for other large impacts (Jones, 2005), and as changes in the geochemical composition of the basalts suggests (Herrin et al., in prep.).

ii) The chosen 790 ka time window is in line with previous volcanic hazard assessments for similar volcanic fields (e.g. Connor et al., 2012; Gallant et al., 2018). Details on the assignment of scoria cone ages appear in Section 5.1.

252

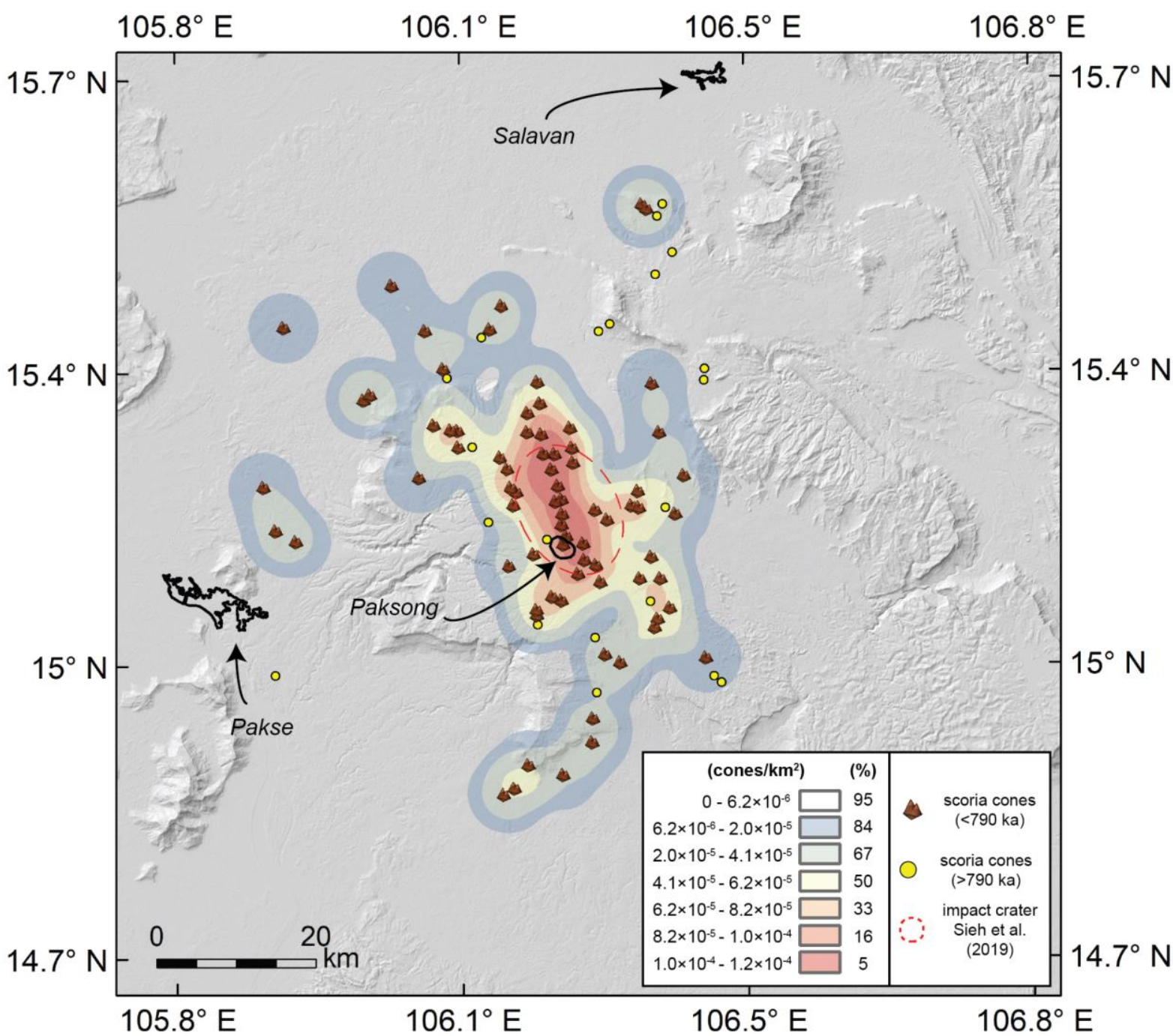

Fig. 4. Vent spatial-density map of the Bolaven Volcanic Field. The KDE utilized only scoria cones younger than the inferred meteorite impact (<790 ka). 
The output of the KDE is a vent spatial-density map with seven classes of visualization, each one corresponding to a range within the density field, expressed as the number of scoria cones per unit area. We selected 30-m as the cell size for the output map, matching the resolution of the SRTM.

260

\subsection{Lava flow simulations}

\subsubsection{MOLASSES}

We use the lava flow inundation model MOLASSES (Gallant et al., 2018) because it requires relatively few input data (lava flow thickness and volume), compared to more complex models where less easily available parameters such as effusion rate, eruption duration, lava flow temperature and composition are also required (e.g. Favalli, 2005; Cappello et al., 2011; Mossoux et al., 2016; Richter et al., 2016). Although MOLASSES does not replicate all the complexities of lava flows in terms of their mechanisms of emplacement, which depend on their physical and chemical properties, it has been proven to effectively replicate flow geometries on a given topography (Gallant et al., 2018; Tsang et al., 2020). In addition, this software (and earlier versions) have been tested for probabilistic-based approaches in volcanic hazard assessments (Connor et al., 2012; Gallant et al., 2018), which was the intent for our study on the BVF. The basic principle of MOLASSES is that an initial limited volume is erupted, with the volume then distributed to adjacent cells, based on distance from the source cell and/or difference in elevation; this process continues until the volume is exhausted (Connor et al., 2012).

\subsubsection{Defining eruption source parameters}

The range of eruption source parameters used for our lava flow simulations are listed in Table 1, and include thickness, volume (total volume to be erupted) and pulse volume (maximum volume for each pulse). In order to choose adequate parameters, we used a combination of field data from the BVF (where measurable or available) and from analogue volcanic fields. We lack a complete record of these parameters for the BVF, because the dense vegetation impedes access, our finite amount of time in the field, and the rarity of exposure of thick flow stacks and their bases. We chose these volcanic fields as analogues for the BVF, based on their similar geological setting (intraplate distributed volcanism), their basaltic compositions, and the availability of data on lava-flow length, thickness and volume: The Shamiram plateau, Armenia (Connor et al., 2012), the eastern Snake River Plain, USA (Gallant et al., 2018), the Northern Harrat Rahat volcanic field, Saudi Arabia (Murcia et al., 2014), and the Auckland volcanic field, New Zealand (Kereszturi et al., 2012). 


\begin{tabular}{lcccc}
\hline & $\min$ & $\max$ & $\log \operatorname{mean}$ & $\log$ SD \\
\hline Thickness $(\mathrm{m})$ & 3.63 & 22.06 & 1.10 & 0.64 \\
\hline Volume $\left(\mathrm{m}^{3}\right)$ & $4.12 \times 10^{7}$ & $3.01 \times 10^{9}$ & 8.46 & 8.47 \\
\hline Pulse volume $\left(\mathrm{m}^{3}\right)$ & $6.80 \times 10^{4}$ & $4.59 \times 10^{5}$ & $\mathrm{n} / \mathrm{a}$ & $\mathrm{n} / \mathrm{a}$ \\
\hline
\end{tabular}

291

292

\subsubsection{Model inputs}

Other inputs for MOLASSES included a Digital Elevation Model (DEM) of the area and previous vent locations. We used the Shuttle Radar Topography Mission (SRTM) DEM, which is available at 1 arcsecond resolution $\left(30 \mathrm{~m} \times 30 \mathrm{~m}\right.$ at BVF), and which we cropped to a total extent of $\sim 12,000 \mathrm{~km}^{2}(102$ $\mathrm{km} \times 118 \mathrm{~km}$ grid) to cover the BVF. The locations of the new vents were stochastically sampled according to the vent spatial density map (Fig. 4). One lava flow was simulated for each vent, with the eruption volume and average lava flow thickness stochastically sampled from within the range considered (Table 1). No correlation was assumed between vent location and eruption volume or lava flow thickness. Volume and thickness were sampled according to a log-normal law, in order to preferentially sample values in the lower/medium range and occasionally in the higher range. This allowed the software to provide lava flow outputs in line with the observations at the BVF and other similar volcanic fields (Connor et al., 2012; Kereszturi et al., 2012; Murcia et al., 2014; Gallant et al., 2018).

We chose to simulate 10,000 individual lava flows, in accordance with other similar probabilistic volcanic hazard assessments (Connor et al., 2012; Gallant et al., 2018). We first ran a sensitivity test to compare the 30-m resolution SRTM with a resampled one at 90-m resolution (100 simulations each), to evaluate the relationship between output resolution and computation time. The computing time was lower for the 90-m resolution DEM ( $3 \mathrm{~h}$ vs $\sim 5 \mathrm{~h})$, however, we noticed a larger extent of the lava flows for the $90-\mathrm{m}$ DEM (overall inundated area $20 \%$ larger). This is because the $90-\mathrm{m}$ SRTM does not capture minor topographic features capable of stopping or deflecting simulated lava flows, particularly in relatively flat areas. Previous studies using MOLASSES, or former versions of MOLASSES, with a probabilistic-based approach (Connor et al., 2012; Gallant et al., 2018), utilised a 90-m DEM. Connor et al. (2012) in particular highlighted the necessity of using higher resolutions to capture minor topographic obstacles and achieve more reliable results, although the same authors considered the 90-m DEM adequate enough for their study. Some studies have used resolutions as high as 10-m or better to conduct volcanic hazard assessments (Vassilopoulou et al., 2002; Capra et al., 2011; Becerril et al., 2014; Deng et al., 2019), however, all these studies were deterministic and conducted on individual volcanic edifices, rather than large volcanic fields, hence involving a lighter computation. 
Using resolutions finer than 30-m for the BVF may provide better results, however, two main issues would be the availability of such DEMs and the computation time required to run 10,000 simulations. Therefore, based on these considerations we decided to proceed with the 30-m resolution DEM.

\subsubsection{Model outputs}

MOLASSES outputs a hit intensity map, on which the intensity is the number of times that each grid cell is inundated (hit) by lava flows. By dividing the number of hits in each grid cell by the total number of simulations performed, we obtained a conditional probability of inundation for each grid cell. A conditional probability assumes that an eruption has occurred somewhere in the BVF.

We defined three hazard zones, coloured yellow, orange and red, based on the probability of inundation, at the $90^{\text {th }}\left(1-78\right.$ hits), $50^{\text {th }}\left(78-390\right.$ hits) and $10^{\text {th }}$ (390-779 hits) percentiles. This choice was somewhat arbitrary but taken to reflect the distributions of hits across the BVF, into areas with relatively low, medium and high probability of inundation.

\subsection{Population, infrastructure and land cover exposure}

We considered population, power lines, power stations, dams, roads, and land cover (i.e. forested and vegetated areas, croplands, built-up areas and water bodies) as critical elements to consider for the BVF because of the intense use of land for agriculture and hydropower production and supply. Other aspects of land use, such as building type and purpose, were not considered here due to the lack and/or reliability of data, or because the exposure to future lava flows was considered very low (e.g. Pakse international Airport).

\subsubsection{Population}

For most population datasets, the population count (or distribution) depends on a series of factors, such as the availability of census information, the disaggregation methods used, and the spatial resolution. In many cases the available results are estimates only (e.g. Freire et al., 2016; Wardrop et al., 2018; Zhang et al., 2018). The BVF is located in the least economically developed country in Asia (Pink, 2016) and one of the least economically developed countries in the world (Delang and Toro, 2011). Moreover, the region of the BVF is predominantly rural; these characteristics make population estimates less reliable when geospatial elements such as nightlights are used as an indication of population density and size (Small et al., 2005). Therefore, we decided to refer to three different, widely used, free and relatively up-to-date population datasets, with different spatial resolutions, in order to provide an indication of the uncertainty in our estimate of people exposed to a future eruption. We used WorldPop2020 (Bondarenko et al., 2020), Global Human Settlement Population 

present advantages and disadvantages. WorldPop integrates census data (where available) and other geospatial datasets (e.g. settlement location and extent, land cover, roads, building maps, satellite nightlights, vegetation, topography) to predict population density at a spatial resolution of $\sim 100 \mathrm{~m}$. Its advantages are the relatively high resolution and data availability for individual countries. Its disadvantages include the lack of reliable data in countries that have not had a census for a long time and limited reliability of data in rural areas. GHS-POP also combines census data and settlement information (from Landsat satellite data for target periods), to produce population estimates at a resolution of $250 \mathrm{~m}$; it has a lower resolution than WorldPop, and the last version was released in 2019. However, it has been proven to provide reliable results when compared with other population datasets (Freire et al., 2016). LandScan uses an automated model to integrate sub-national level census counts for each country and geospatial datasets, including land cover, roads, slopes, urban areas, village locations, and high-resolution imagery analysis; the resultant population count is based on a 24-hours average. Advantages of this dataset include these: (i) Weighting of population count for each country, based on socio-economic and cultural understanding of the area; and (ii) release of an updated version every year. Some of its limits are its relatively coarse resolution ( $\sim 1 \mathrm{~km})$ and the fact that data seem to be less reliable at the transition between urban and rural areas (Calka and Bielecka, 2019).

\subsubsection{Infrastructure}

We used datasets from different sources for different infrastructure types, based on data accessibility, availability, and date of release. We used Open Street Map (OpenStreetMap Foundation \& Contributors, 2016) for roads; Open Development Laos (2016) for dams; and World Bank (2019) for power lines and power stations. Following the Open Street Map classification, roads were further subdivided into Type-1 and Type-2 (Table 2). The former consists of roads for public use (e.g. country's roads, links between cities), the latter includes roads for private or semi-private use (e.g. access to housing, industrial or agricultural use). Note that for the purpose of this paper, roads for exclusive pedestrian use were not included.

\subsubsection{Land cover}

For land cover, we used Copernicus Global Land Service (CGLS-LC100, 2019), which has a spatial resolution of $\sim 100 \mathrm{~m}$. We calculated the total area for each land class based on the cover fraction classification, where each pixel represents a fraction (0-100\%) for a particular land class. The classes considered were forest, cropland, built-up and water (seasonal and permanent); other types of natural 
All these datasets were overlaid on the probabilistic inundation map and processed through ArcMap 10.7.1, in order to quantify the exposure in terms of numbers of people, count of dams and power stations, length of roads and power lines, and surface area of land cover for each class, within each defined lava flow hazard zone.

Table 2. Road types considered for this work, based on OpenStreetMap definitions.

\begin{tabular}{|c|c|c|}
\hline $\begin{array}{l}\text { This work } \\
\text { classification }\end{array}$ & ${ }^{a}$ OSM classification & OSM definition \\
\hline Type 1 & $\begin{array}{l}\text { Secondary link } \\
\text { Tertiary } \\
\text { Unclassified }\end{array}$ & $\begin{array}{l}\text { A major highway linking large towns } \\
\text { Slip roads/ramps and "channelised" at-grade turning } \\
\text { lanes that connect through carriageways/through } \\
\text { lanes of a Primary to other minor roadways } \\
\text { A highway that is not part of a major route, but forms } \\
\text { a link in the national network } \\
\text { Used to identify slip roads/ramps and "channelised" } \\
\text { at-grade turning lanes connecting the through } \\
\text { carriageways/through lanes of a Secondary other } \\
\text { minor roadways } \\
\text { Roads connecting smaller settlements, and within } \\
\text { large settlements for roads connecting local centers. } \\
\text { In terms of the transportation network, } \\
\text { OpenStreetMap "tertiary" roads commonly also } \\
\text { connect minor streets to more major roads. } \\
\text { Minor public roads typically at the lowest level of the } \\
\text { interconnecting grid network }\end{array}$ \\
\hline Type 2 & $\begin{array}{c}\text { Residential } \\
\text { Service }\end{array}$ & $\begin{array}{l}\text { Roads for accessing residential areas and in } \\
\text { residential areas but not normally used as through } \\
\text { routes } \\
\text { Roads for access to a building, service station, } \\
\text { beach, campsite, industrial estate, business park, etc. } \\
\text { Roads mostly for agricultural use, forest tracks etc. } \\
\text { Often unpaved (unsealed) but may be paved tracks } \\
\text { Suitable for two-track vehicles, such as tractors or } \\
\text { jeeps }\end{array}$ \\
\hline
\end{tabular}

\subsection{Field data}

For the purpose of this work, here we concentrate only on post-impact volcanic products (790 ka or younger). More details appear on the detailed map in the Data Repository 


\subsubsection{Lava flows}

Post-meteorite impact lava flows vary in length between a few hundred meters and a few tens of kilometres (up to $\sim 50 \mathrm{~km}$, northern flow complex), for a total areal extent of about $3900 \mathrm{~km}^{2}$. Thickness of individual flows was estimated based on observations from locations in the field (see examples in Fig. 3) and additional geospatial analysis through ArcMap, to obtain a range of average thickness between about 6 and 14 meters. Volumes were calculated based on the surface area of the mapped flows and thickness information, to obtain estimates in the range $\sim 0.06-3.4 \mathrm{~km}^{3}\left(6 \times 10^{7}\right.$ $\left.3.4 \times 10^{9} \mathrm{~m}^{3}\right)$. Note that thickness and volume were calculated for eight relatively young flows $(\leq 120$ ka), chosen to be representative of the latest activity of the field, and because they presented advantages in terms of field exposure, preservation and accessibility, compared to other post-impact lava flows, as highlighted by Sieh et al. (2019), with intense laterization and saprolitization for most basalts on the field (Fig. 3).

\subsubsection{Scoria cones}

Among the 67 available dates from the BVF, 47 are from post-meteorite impact lavas (Fig. 2 and Table S1, supplementary material). Two of these are from lava within scoria cones. Geochronological and geochemical data from scoria cones are sparse, because they are commonly in thick, untracked jungle and their clastic deposits are more highly weathered than lava flows (only one scoria cone was successfully dated, $\sim 1.5 \mathrm{~km}$ E of Paksong, $200 \pm 9 \mathrm{ka}$ ). Therefore, most scoria cones were either assigned an absolute age, based on ${ }^{40} \mathrm{Ar}-{ }^{39} \mathrm{Ar}$ dates of lava flows that erupted from that cone (e.g. Fig. 3e), or assigned an age interval (if an absolute age was not available for any of the flows that emanated from beneath that cone). Out of the 97 scoria cones mapped (Fig. 2), 76 were inferred to be younger than $790 \mathrm{ka}$, whereas 21 were either older than $790 \mathrm{ka}$ or indeterminate in age/age-interval.

Here we assume that each vent was produced by a single eruptive event (following the definition of vents vs events as in Gallant et al., 2018). This assumption was based on the lack of field information for most scoria cones (lack of fresh scoria cones deposits and/or lack of accessibility), resulting in missing information usually needed to link an eruptive source to its deposits; for example, use of geochemical compositions and absolute ages of scoria cones, to match (or not match) them with nearby lava flows and other scoria cones. More discussion around the issue of vents vs events is reported in Section 6.

\subsection{Vent spatial density and probabilistic inundation map of the BVF}

The approximately $30 \%$ of scoria cones within the highest density fields ( $5^{\text {th }}$ to $33^{\text {th }}$ percentile) form a N-S band across the NW portion of the plateau (Fig. 4). Some isolated clusters of lower density are 
to the NE ( $\sim 15 \mathrm{~km}$ south of Salavan), to the W ( 10km north-east of Pakse), and about $35 \mathrm{~km} \mathrm{~N}$ of Pakse. Curiously, the area with the highest concentration of vents is nearly coincident with the inferred location of the Australasian impact crater (Fig. 4).

As one might expect, the highest probabilities of inundation by future eruptions of lava are in the region of greatest density of existing vents. The area with the highest probability of inundation (red zone: $3.89-7.79 \%$ ) is nearly coincident with the area with the highest density of vents, whereas the lowest-probability area (yellow zone: $0.01-0.78 \%$ ) has the lowest vent density. The lowest conditional probability of lava flow inundation (yellow zone) has the largest total surface area, at $3508 \mathrm{~km}^{2}$, while the orange zone and red zone cover $1804 \mathrm{~km}^{2}$ and $285 \mathrm{~km}^{2}$, respectively. A total area of approximately $5600 \mathrm{~km}^{2}$ is at threat from potential inundation by lava flows in a future eruption. For any individual eruption, the area affected ranges from $\sim 2 \mathrm{~km}^{2}$ to $\sim 740 \mathrm{~km}^{2}$.

\subsection{Exposure}

\subsubsection{Population}

The three population datasets yield a range of $\sim 274,000$ to $\sim 358,000$ people within the potentially inundated area. Most ( 189,000 to $\sim 219,000)$ live in the yellow zone. About 44,000 to $\sim 117,000$ live in the orange zone and 12,000 to 26,000 live in the red zone. All three of the large cities are within the lowest of the three zones. Stated in percentages and using the WorldPop2020 and GHS-POP 2019 databases, $60 \%$ live in the yellow zone, $33 \%$ in the orange zone, and $7 \%$ in the red zone. The values using LandScan2019, are $80 \%$ in the yellow zone, $16 \%$ in the orange zone, and $4 \%$ in the red zone (Table 3).

\subsubsection{Infrastructure}

There are $2678 \mathrm{~km}$ of roads within the three potentially inundated areas (Fig. 5). Of these, 1479 $\mathrm{km}(55 \%)$ are within the yellow zone, $950 \mathrm{~km}$ (35\%) within the orange zone, and $250 \mathrm{~km} \mathrm{(10 \% )} \mathrm{are}$ within the red zone. In terms of road type, the balance is slightly in favour of Type-1 roads for yellow and orange zones ( $55 \%$ and $59 \%$ respectively), and roughly the same for the red zone (Type- $1=49 \%$, Type- $2=51 \%$ ). This reflects the underlying proportion of roads, which are approximately $56 \%$ Type- 1 and $44 \%$ Type-2 across our study area (see also Fig. 5).

Across the entire hazard area are $416 \mathrm{~km}$ of power lines. Of these, $259 \mathrm{~km} \mathrm{(62 \% )} \mathrm{are} \mathrm{in} \mathrm{the} \mathrm{yellow}$ zone, $120 \mathrm{~km}$ in the orange zone (29\%), and $37 \mathrm{~km} \mathrm{(9 \% )} \mathrm{in} \mathrm{the} \mathrm{red} \mathrm{zone.} \mathrm{Along} \mathrm{these} \mathrm{power} \mathrm{lines,} \mathrm{there}$ are two power stations (both in the yellow zone) and one dam (orange zone). Another dam is located in the orange zone (Table 4, Lat: $15.35^{\circ}$; Long: $\left.106.31^{\circ}\right)$, but not yet connected to the main array of 
power lines (the Laos government planned to build additional $578 \mathrm{~km}$ of power lines in the region,

464 including $5 \mathrm{~km}$ to connect this dam to the main network, according to the World Bank, 2019).

465

466 Table 3. Population exposure results from different datasets.

\begin{tabular}{|c|c|c|c|c|}
\hline & $\begin{array}{c}\text { Total } \\
{ }^{\mathrm{a}}\left(5597 \mathrm{~km}^{2}\right)\end{array}$ & $\begin{array}{l}\text { Yellow zone } \\
\left(3508 \mathrm{~km}^{2}\right)\end{array}$ & $\begin{array}{l}\text { Orange zone } \\
\left(1804 \text { km²) }^{2}\right.\end{array}$ & $\begin{array}{l}\text { Red zone } \\
\left(285 \mathrm{~km}^{2}\right)\end{array}$ \\
\hline WorldPop & 316,074 & $188,568(59.7)^{b}$ & $104,934(33.2)$ & $22,572(7.1)$ \\
\hline GHS & 358,331 & $214,923(60.0)$ & $117,014(32.7)$ & $26,372(7.4)$ \\
\hline LandScan & 274,013 & $218,650(79.8)$ & $43,770(16.0)$ & $11,590(4.2)$ \\
\hline
\end{tabular}

467 a Surface area considered for the population count

$468{ }^{b}$ Fraction (\%) of people in that particular hazard zone, respect to the total population across all hazard zones.

Table 4. Exposure results for Dams and Power stations.

\begin{tabular}{ccccc}
\hline Category & Latitude & Longitude & $\begin{array}{c}\text { Conditional } \\
\text { Probability of } \\
\text { inundation (\%) }\end{array}$ & $\begin{array}{c}\text { Hazard } \\
\text { zone }\end{array}$ \\
\hline Dam & 15.35 & 106.31 & 1.74 & Orange \\
\hline Dam & 15.40 & 106.28 & 0.87 & Orange \\
\hline $\begin{array}{c}\text { Power } \\
\text { station }\end{array}$ & 15.48 & 106.28 & 0.01 & Yellow \\
\hline $\begin{array}{c}\text { Power } \\
\text { station }\end{array}$ & 15.42 & 105.88 & 0.59 & Yellow \\
\hline
\end{tabular}

471 


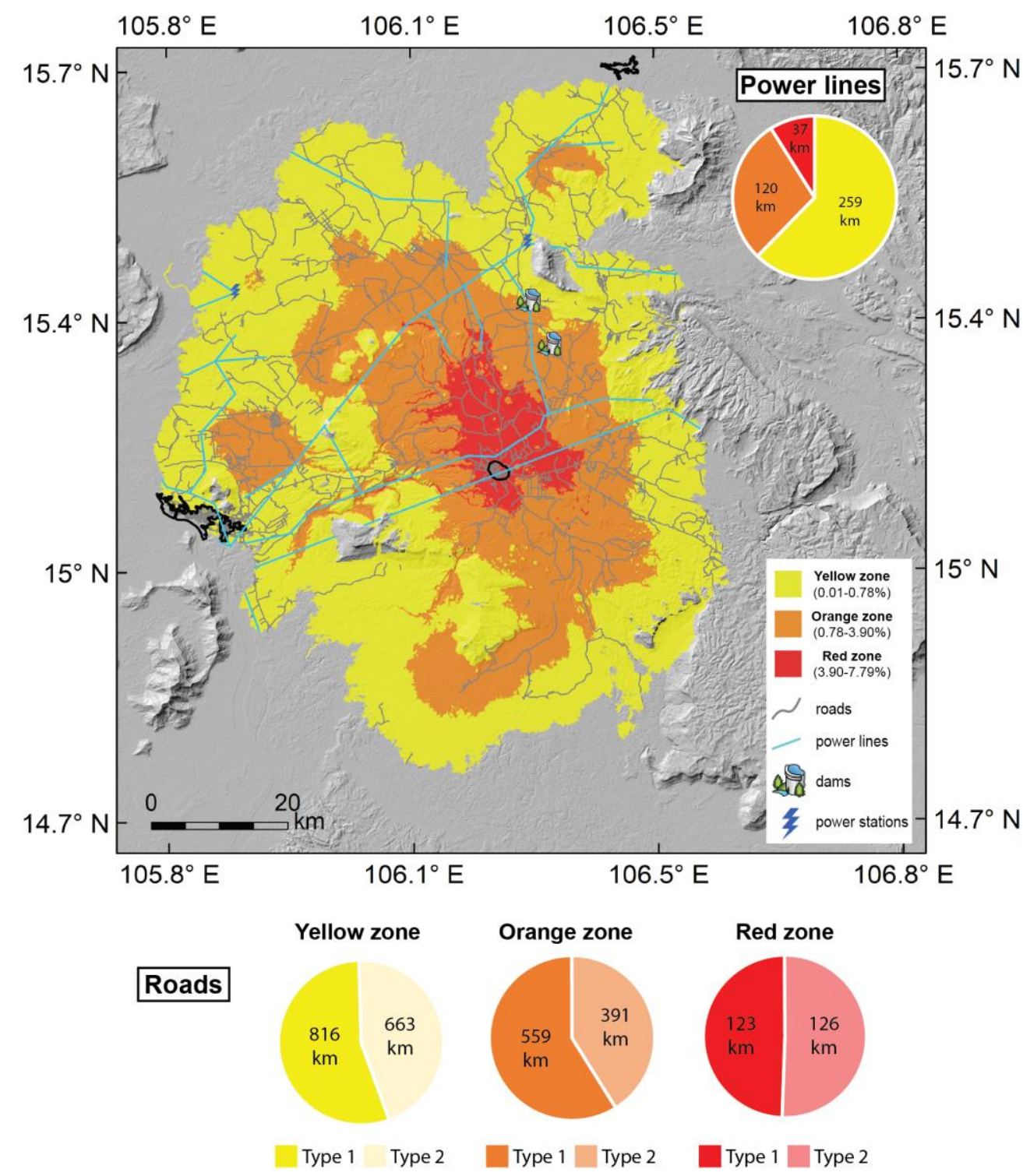

Fig. 5. Probabilistic inundation map of the BVF and exposed key infrastructure for the three hazard zones. Percentage of power lines within each zone as a pie chart in upper right, and percentage of road types for each zone as pie charts at the bottom.

\subsubsection{Land Cover}

Across all hazard zones (Fig. 6), $4996 \mathrm{~km}^{2}$ (89\%) of land is covered in forest and sparse vegetation. Cropland covers $514 \mathrm{~km}^{2}(9 \%)$, built-up areas cover $73 \mathrm{~km}^{2}(1 \%)$, and permanent and seasonal water cover $15 \mathrm{~km}^{2}(<1 \%)$. In particular, the yellow zone encompasses $3060 \mathrm{~km}^{2}$ (87\%) of forest and sparse vegetation, $387 \mathrm{~km}^{2}$ (11\%) of cropland, $48 \mathrm{~km}^{2}(1 \%)$ of built-up areas, and $13 \mathrm{~km}^{2}$ (>1\%) of water. The orange zone contains $1686 \mathrm{~km}^{2}$ (94\%) of forest and sparse vegetation, $98 \mathrm{~km}^{2}$ (5\%) of cropland, 19 $\mathrm{km}^{2}(1 \%)$ of built-up areas, and $1.4 \mathrm{~km}^{2}(>1 \%)$ of water. The red zone includes $250 \mathrm{~km}^{2}(88 \%)$ of forest and sparse vegetation, $29 \mathrm{~km}^{2}(10 \%)$ of cropland, $5 \mathrm{~km}^{2}(2 \%)$ of built-up areas, and $0.6 \mathrm{~km}^{2}(<1 \%)$ of water. 


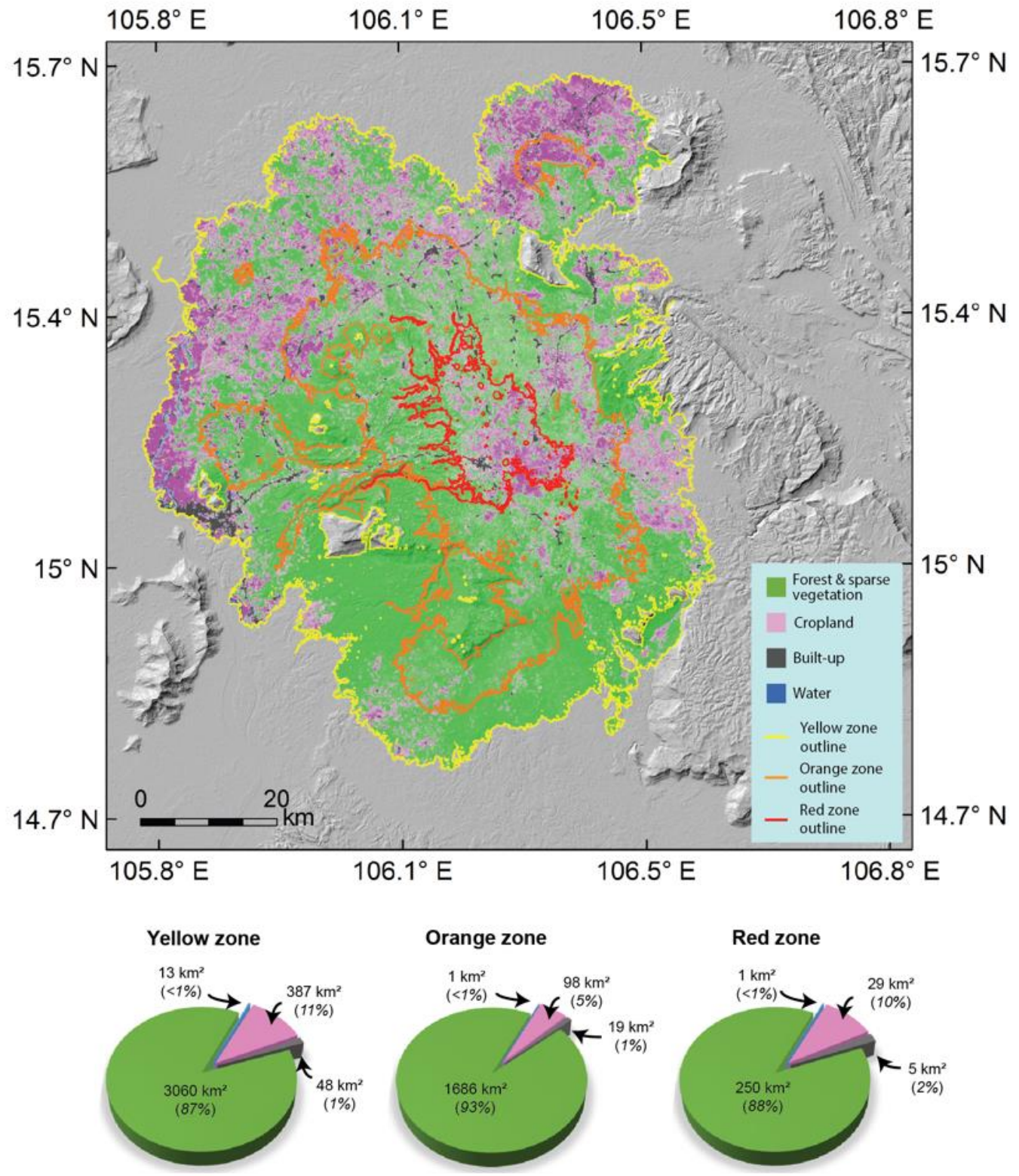

Fig. 6. Land cover exposure map. Shades of the same colour type represent fractions (e.g. light pink $=1 \%$ of cropland, dark pink $=100 \%$ of cropland, for that particular pixel), that have been considered for the total calculation of surface area (see pie charts) for each land class.

\section{Discussion}

Volcanic risk assessments require information on several aspects, such as volcanological setting (e.g. central volcano, volcanic field), eruptive style (e.g. explosive, effusive), hazard type (e.g. ash fallout, pyroclastic flows, lava fountains, lava flows, lahars), and the geographic context of the area assessed (how the hazards can impact the local population and/or their activities). Their robustness often depends strongly upon the availability of data for that particular area (reliable and up-to-date geological, hazard, exposure and vulnerability information). Here we did not conduct any vulnerability 
assessment due to the lack of information. Below, we discuss the results and limitations of the present research, based on evaluating likely hazard, exposure and potential impacts in the BVF area in case of renewed volcanism, the first such assessment in northern SE Asia for a volcanic field.

\subsection{Scoria cones distribution and significance}

Volcanic fields around the world show a variety of spatial features of their eruptive centres, from clustered monogenetic cones (e.g. Connor et al., 2012; Kereszturi et al., 2012; Gallant et al., 2018) to cone alignments along fissures (e.g. Belousov et al., 2015; Kubanek et al., 2015; Pedersen et al., 2017). Understanding the distribution of eruptive centres within a volcanic field may help understand the likely location of future activity at that field, hence allowing more accurate hazard and exposure assessments. The location of the post-impact scoria cones on the BVF, hence the area with the highest probability of future vent opening, seems related to the impact crater structure rather than to the local tectonic stress.

From a tectonic perspective, a report from the Ministry of Energy and Mines (Japan International Cooperation Agency, 2008) and mapping effort from this work (https://researchdata.ntu.edu.sg/privateurl.xhtml?token=605d1696-0a8d-47cf-afeb-5e18398a6ef2), highlighted the presence of several tectonic structures (a syncline crossing the plateau, a syncline/anticline pair just NE of the Plateau, and several reverse faults to the E of the plateau), whose $\sigma 1$ is oriented NE-SW. Field evidence and Ar-Ar dating of a nearby lava flow indicate that these structures (particularly the syncline/anticline pair NE of the Plateau) are younger than $2.9 \mathrm{Ma}$, and they likely represent the latest deformation pattern in this region. If there was a direct link between this local stress field and the pattern of scoria cones, then it would be parallel to the $\sigma 1$ (Nakamura, 1977), which is not the case here, given the N-S orientation of the scoria cones.

On the other hand, the N-S aligned post-impact scoria cones on the BVF, besides being encompassed within the inferred location of the Australasian impact crater, have an inferred age lower than the impact itself, with pre-impact scoria cones showing a more widespread distribution across the field (Fig. 4). This may suggest an existing link between the meteorite impact and the postimpact volcanism, as hypothesized for other large-scale meteorite impacts (Jones, 2005), or in part may reflect a bias from the lack of exposure of older scoria cones (buried or eroded), potentially hiding older (or unknown) regimes.

Although additional data are needed (including a complete dataset of seismic tomography, geochemical data, and absolute ages of scoria cones) to better constrain the reasoning behind this 
distribution, our scoria cones spatial distribution analysis provides a first-time indication of the location of future volcanic activity on the BVF, which largely coincides with the location of the largest known young meteorite impact on Earth.

\subsection{Exposure analysis}

In this section we discuss exposure and impacts on populations, infrastructures and landcover, based on our lava flow simulations and mapping.

The population exposure results show that there is some variation among all datasets. In particular, the highest variation is observed for LandScan, where the total count is between $13 \%$ and $24 \%$ smaller than that for WorldPop and GHS-POP (Table 3) respectively, and also different for individual hazard zones (20\% higher for yellow zone, $17 \%$ smaller for orange zone, and $3 \%$ smaller for red zone). GHS$P O P$ has the highest total population count $(\sim 358,000)$, but if we consider the fractions for each hazard zone, WorldPop and GHS-POP share the same \% of people. All three datasets are based on census data and geospatial information. Decadal censuses are conducted in Laos, with the last conducted in 2015, hence relatively recent. A major difference among the considered datasets is the spatial resolution, with LandScan having the coarsest one. In addition, as anticipated in Section 4, LandScan has been found to underestimate population counts at the transition between urban and rural areas (Calka and Bielecka (2019) and the lower LandScan population count on the BVF may reflect the presence of sparse villages in the region, surrounded by forests and croplands (Fig. 6). WorldPop and GHS-POP may present some limitations as well, however, the results are relatively consistent when total counts and fractions across the different hazard zones are compared. For the purpose of this study, the application of largely used, and freely available population datasets allowed us to detect the minimum number of people potentially exposed to lava flows in case of an eruption on the BVF.

Generally, casualties are less likely from lava flows than from pyroclastic flows, ash fallout, ballistics, or lahars (Brown et al., 2017). However, lava flows can significantly impact settlements and 555 livelihoods, and rehabilitation/recovery can take years and involve high costs for the local administrations (Williams and Moore, 1983; Baxter et al., 2002; Jenkins et al., 2017; Tsang and Lindsay, 2020; Meredith et al., in review). An exhaustive review on impacts from lava flows is provided by Harris (2015). He considered six main categories potentially impacted from lava flows: 1) humans and animals; 2) buildings; 3 ) communication, utilities and machinery; 4) agriculture, habitat and natural vegetation; 5) economic activity; and 6) social fabric. All these categories would have a different impact based on factors such as the characteristics of the flow (e.g. viscosity, advancement rate, 
(e.g. maintaining a safe distance from the flows), quality and type of infrastructure, and response strategies (e.g. redirection of lava flows to less exposed/vulnerable areas). Education of the population to the likely hazards posed by lava flows, and their long-term impacts can help communities adapt and recover (Tsang and Lindsay, 2020).

Cities on and around the BVF have calculated conditional probability of inundation that vary from $0.01 \%$ to $7.79 \%$ across the field (Fig. 5). Pakse is the largest and most populated city in southern Laos, and ${ }^{40} \mathrm{Ar}-{ }^{39} \mathrm{Ar}$ dating shows that the majority of the city is built upon a lava flow $\sim 180$ ka old, and a flow likely $<40 \mathrm{ka}$ is nearby. This low spatial density of past flows puts Pakse within the least exposed zone, our Yellow Zone (Fig. 5). It has about a $0.05 \%$ likelihood of being reached by lava flows during any future eruption. That is to say, there is one chance in 2,000 that any future flow will enter the city. Paksong, the second largest city in the area, sits within the Red Zone. Although the flow that it sits upon is about the same age as the one underlying Pakse ( $185 \mathrm{ka}$ ), Paksong is within a few kilometers of many young flows that range in age from $\sim 75$ to $\sim 200 \mathrm{ka}$. The likelihood of a future flow reaching Paksong is 6\% (or about one chance in 17), about a hundred times higher than one reaching Pakse. The city of Salavan is north of the BVF and is built on young fluvial sediments rather than lava flows. Our simulations thus show a conditional probability of inundation of $0 \%$. That is not to say that there is absolutely no possibility of inundation by lava, but the likelihood is vanishingly small. Salavan is more likely to be affected by other aspects of an eruption. For example, a flow down the north side of the plateau could reach and dam the Xedon River, flooding parts of the plain around and including the city.

People can be significantly affected by damage to infrastructure. Disruption of power production and distribution could result in loss of access to power for most areas in the Champasak, Salavan, and Xekong provinces. Here we only consider hydropower, for the reasons explained in Section 2, which is produced by the operational dams in the area, and distributed through a network of power lines (Fig. 5). Eruption-related damage to one of the two dams located in the orange zone, which is directly connected to one of the power lines, may create a disruption in the immediate power production and supply. Power lines on and around the BVF cover the entire width of the potentially inundated area, therefore, regardless of where the damage will take place, it may affect other areas of the plateau, potentially also affecting urban sites located outside of this area (e.g. Salavan). In addition, most of the power produced in Laos is exported to Thailand; therefore, international trading can undergo an impact as well. Another key infrastructure that can suffer an impact, affecting people, is roads. This can happen through restricted or blocked access for: 1) delivery of essential goods (e.g. food, medicines) to the areas affected; 2) emergency response or maintenance vehicles, for example to 
people, who may not be able to reach their work sites or visit family members in nearby cities or villages who need assistance; 4) trading with nearby countries (Thailand, Cambodia and Vietnam).

Another key asset to consider in exposure assessments is land cover. Our analysis of the potentially inundated area shows an obvious predominance of forest and other types of natural vegetation, followed by croplands, built-up areas and water bodies (Fig. 6). An eruption on the Bolaven plateau affecting them can result in impacts for the local and national economy. Forests, for example, may be ignited by lava flows (e.g. Ainsworth and Kauffman, 2009; Harris, 2015), particularly in the drier season, and fires can propagate over a large area, potentially damaging infrastructures and natural historical sites. Cropland and built-up land classes, which seem to be linked across the whole field (built-up areas being surrounded or adjacent to areas with high cropland fraction) double from orange zone to red zone ( $5 \%$ to $10 \%$ for cropland, and $1 \%$ to $2 \%$ for built-up areas), despite the red hazard zone being $~ 6$ times smaller than the orange hazard zone; this suggests that the high area of the plateau (also the red zone: Fig 6) has the most favourable conditions for agricultural use. Although cropland was not subdivided into different agricultural classes here (lack of reliable and/or up-to-date data), coffee production on the Bolaven plateau represents about $95 \%$ of the total amount produced in Laos (Toro, 2012). A future eruption on the Bolaven plateau could therefore affect the socioeconomic wellbeing of those in the region, who rely on coffee as their source of income. This in turn can impact the economy of the whole country (Toro, 2012), either directly, if coffee plantations are inundated by lava, or indirectly, if roads linking cities or countries are inundated by lava and inaccessible for months/years affecting transport to major cities for coffee processing and export. Official GDP data from Laos are available for the agriculture sector as a whole, but not available for individual sub-sectors such as coffee.

In order to further evaluate the knock-on consequences from an effusive eruption on the BVF, upto-date information about infrastructure and land cover is needed.

\subsection{The role of external water in potential explosive activity on the BVF}

Explosive interaction between magma and water (here broadly referred to as phreatomagmatic activity), is a potentially hazardous volcanic phenomenon known to occur in a wide range of environmental settings (e.g. Thorarinsson, 1964; Fagents and Thordarson, 2007; Wohletz et al., 2013; Verolino et al., 2018, 2019; Dürig et al., 2020a, 2020b), including areas dominated by lava flow effusions (e.g. Lorenz and Haneke, 2004; Hamilton et al., 2010; Fitch and Fagents, 2020). Although we found no direct evidence of past explosive magma-water interaction on the BVF, the abundance of water in this area may lead to such activity in case of eruption. Below we address three different 
potential mechanisms leading to such behaviour on the BVF: (i) new vents opening underneath standing water (reservoirs or rivers) (Fig. 7); (ii) rising magma interacting with groundwater; and (iii) lava flows interacting with surface water or water-saturated sediments. The hazards associated with all these mechanisms are similar, including formation of pyroclastic surges, delivery of hot ash, lapilli and bombs into the atmosphere and to nearby areas. In addition, if an eruption initiates in a large water reservoir, the consequence can be generation of a tsunami (e.g. Waters and Fisher, 1971; Vaughan and Webley, 2010; Sandri et al., 2012; Nomikou et al., 2014; Deligne et al., 2017). All these hazards can be more dangerous to people than lava flows, but also can cause damage to infrastructure and land cover (Jenkins et al., 2015).

Among the 10,000 simulated vents, $0.31 \%$ of them $(n=31)$ opened beneath standing water. Explosive interactions between standing water and rising magma, although more common in oceans, do occur in lakes (e.g. Németh et al., 2006; Verolino et al., 2018, 2019) and rivers (e.g. Muller and Veyl, 1956; Hamilton and Myers, 1963; Hackett and Morgan, 1988). Should an eruption start on the Bolaven plateau within water, it would likely be phreatomagmatic in style. Paksong is the city with the highest chance of being inundated by lava flows, because of the high concentration of vents nearby; among the submerged simulated cones, two are located less than $500 \mathrm{~m}$ from its administrative boundaries, and eight are located $\sim 4 \mathrm{~km}$ away.

Interaction between rising magma and groundwater on the BVF is also possible. The Bolaven plateau represents one of the rainiest regions in Laos, with a long-term precipitation average of $\sim 2500$ $\mathrm{mm} /$ year (Laos average $1500 \mathrm{~mm} /$ year) (Viossanges et al., 2017). This, together with the geological and geomorphological characteristics of the area, make it an exceptional place for groundwater storage, productivity and recharge (Viossanges et al., 2017). Having such availability of groundwater beneath a volcanic field may result in phreatomagmatic activity, in case of renewed volcanism in the area. Explosive interactions between rising magma and groundwater are more likely to take place if they initiate at depths $<1 \mathrm{~km}$ below the water table (Valentine and White, 2012), resulting in the

655 formation of a maar-diatreme volcano. Borehole data suggest that groundwater of the Bolaven plateau can be found at a depth of a few tens of meters (Viossanges et al., 2017), hence retaining the potential to trigger phreatomagmatic eruptions with centers proximate to the surface, resulting in more hazardous scenarios. The extent of the Bolaven plateau $\left(\sim 6000 \mathrm{~km}^{2}\right)$, and its abundance of groundwater, suggests that the probability of this type of volcanic activity is clearly higher than phreatomagmatic activity produced by magma and standing water on the plateau. 
no involvement of new magma, and the explosions can take place even kilometres away from the vent), forming rootless cones (e.g. Boreham et al., 2020; Fitch and Fagents, 2020). Secondary phreatomagmatic explosions are more likely if there is interaction between fresh low-viscous lava and water-saturated sediments in an unconfined environment (Zimanowski and Wohletz, 2000; Schipper et al., 2011). In most cases they are relatively weak, with erupted products confined to maximum a few ten of meters from the secondary vent (e.g. Fagents and Thordarson, 2007; Fitch and Fagents, 2020), however, Belousov et al. (2011) showed that they can be equivalent to primary phreatomagmatic eruptions in terms of magnitude and potential hazards (formation of a vertical eruptive columns up to $7 \mathrm{~km}$ high, and pyroclastic flows travelled up to $2 \mathrm{~km}$ from the explosion site), if they occur on steep slopes. A common scenario of these interactions is a lava flow entering a river, lake, or ocean, without causing an explosion. The lava solidifies and creates new land, resulting in deflection (e.g. Pedersen et al., 2017) or blocks the river, with consequent upstream flooding (Boreham et al., 2020). Approximately $60 \%$ of the simulated inundation area of the BVF is covered by post-impact lava, with a good part of it turned into saprolite, and the remaining $\sim 40 \%$ being Mesozoic (mudstone and sandstone) and Holocene fluvial/lacustrine sediments (loose coarse silt to fine sand). This area encompasses a total of about $15 \mathrm{~km}^{2}$ of surface water (Fig. 6) with $\sim 1400 \mathrm{~km}$ of rivers/streams (Fig. 7), and this estimate does not include the water-saturated sediments, that may be found either in the saprolites/laterites, or in the loose fluvial/lacustrine units. Therefore, this analysis shows that there is potential to trigger secondary phreatomagmatic explosions on the BVF, as well as non-explosive interactions, that can result in damming of a river. Both scenarios can be hazardous for the local communities, either directly (e.g. pyroclastic flows, ejecta, lahars), or indirectly (e.g. flooding and power disruption). However, given the high variability of the physical properties of the sediments involved in the area, the complexity of the topography (flat areas versus steep canyons), and the availability of water which depends on seasons, we cannot say with what frequency in time and space they will occur.

As anticipated at the beginning of this section, we found no evidence of explosive magma-water interactions on the BVF, after a qualitative morphologic analysis of the scoria cones. One reason could be that its extremely wet and warm climate promotes rapid erosion of pyroclastic deposits. Another reason could lie in the availability of water. Heaney (1991) proved through fossil pollen records that the climatic conditions in the Late Pleistocene were much drier than today for this region. Most of the youngest lava flows on the BVF are latest-Pleistocene, although some flows may well be Holocene in age. At this time, the climate was shifting toward drier conditions until reaching the Last Glacial Maximum ( 18 ka; Heaney, 1991). Therefore, it is likely that at the time of the most recent eruptions on the BVF there was less availability of water than nowadays. However, we acknowledge that some 
697

698

699

700

of these landforms might exist under younger deposits, or hidden by intense erosion/dense vegetation. On the other hand, non-explosive interactions largely occurred on the BVF; one example of river diversion is reported in Fig. $3 \mathrm{~d}$.

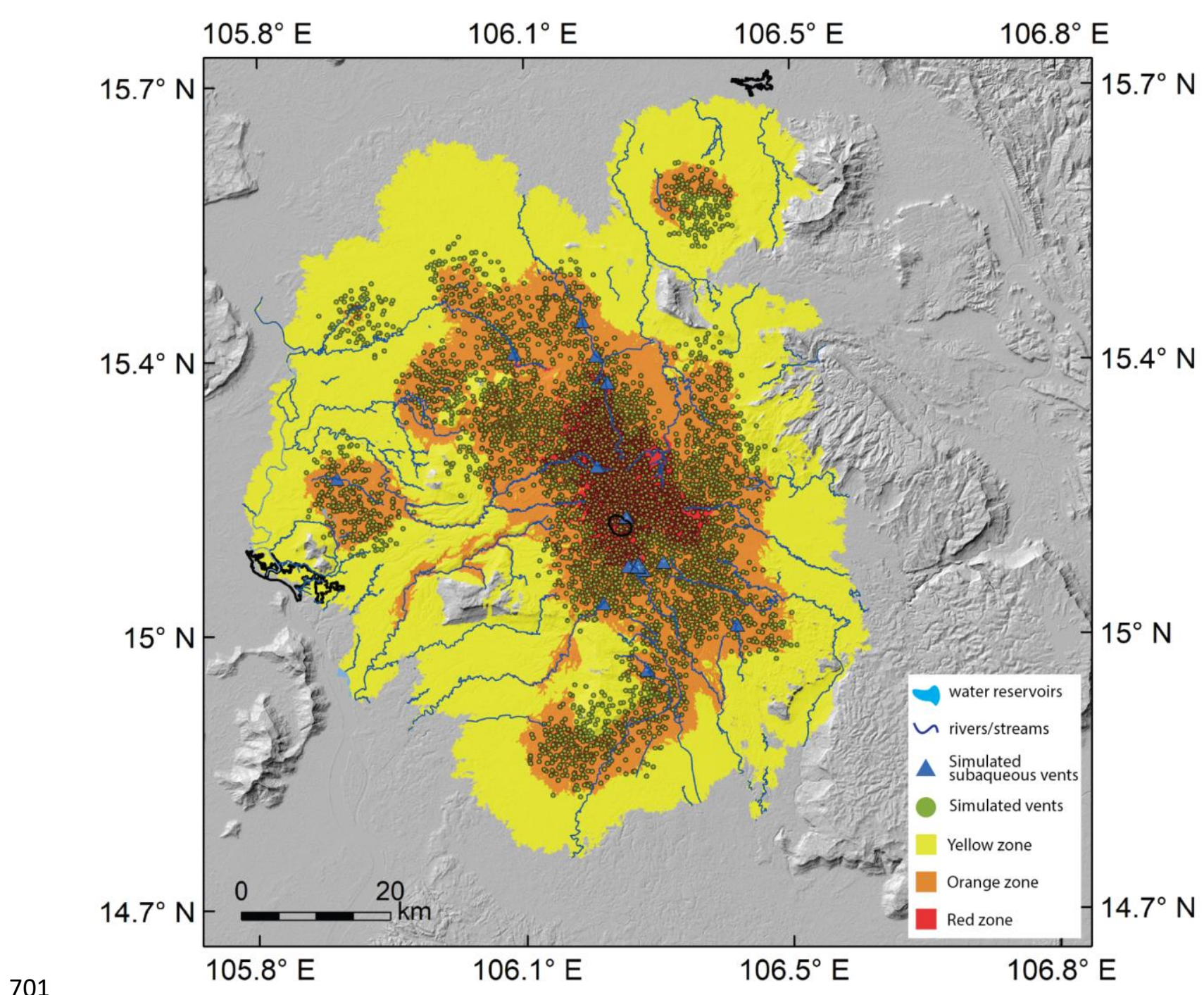

Fig. 7. Probabilistic inundation map with the location of the simulated vents $(n=10,000)$ and simulated vents that opened within water bodies $(n=31)$.

\subsection{Average Recurrence Interval (ARI) of the BFV}

Evaluating the Average Recurrence Interval at volcanic fields is key in volcanic risk assessments. Previous authors have estimated ARI's for volcanic fields by simply dividing a considered timeframe by the number of eruptions that occurred within that period. One common challenge in these assessments, however, is to distinguish eruptive vents (i.e. one vent $=$ one eruption) from eruptive events (i.e. one or more vents related to the same eruption). Runge et al. (2014) and Gallant et al. 

Plain respectively, to provide the minimum number of eruptions. In particular, they used statistical methods based on spatial-temporal relationships of the vents to convert them into events and obtain the recurrence intervals at the selected locations. However, the areas investigated have high levels of exposure (e.g. little or no vegetation), which made it easier to understand the stratigraphic relationships between lava flows and/or vents, and have a well-known volcanic history with absolute ages available for all the vents.

Since the BVF sources are neither well exposed nor thoroughly dated, we approached the challenge of estimating eruption recurrence by considering two sets of data. One set comprises all the postmeteorite impact absolute ages for the BVF lava flows, which differed significantly in age and/or in space. We considered any two neighbouring flows with significantly different absolute ages to represent separate eruptive events. This analysis resulted in 40 eruptions in the last 790 ka, equivalent to an ARI of 19,750 years (Fig. S1, supplementary material). If we apply the same exercise to the last $135 \mathrm{ka}$, the number of eruptive events is 15 , resulting in an ARI of 9,000 years. This difference is likely due to the fact that the latest period of activity on the plateau is more represented in the field, and probably more representative of the latest ARI at Bolaven, hence more realistic. Instead, if we consider the whole post-impact period (i.e. $790 \mathrm{ka}$ ), we may lose information from older (buried?) flows, resulting in a longer ARI. The second set, instead, includes the scoria cones for the ARI estimate. If we assume that all 76 cones represent separate events over the past $790 \mathrm{ka}$, we calculate an ARI of 10,395 years. Although it is possible that some of these scoria cones might have formed during the same eruptive event, it is also very likely that some of the eruptions did not produce any cone, and that we missed detecting some eruptions because their cones are buried or eroded beyond recognition. This estimate is in line with the ARI estimate from the lava flow absolute ages for the last $135 \mathrm{ka}$.

From a field perspective, there are three flow complexes that are covered by immature first-growth forests. The southern flow complex, reported in Fig. $3 d(<40 \mathrm{ka})$, has the sparsest such cover; the western flow complex ( $25 \mathrm{~km} \mathrm{~N}$ of Pakse) also underlies a first-growth immature forest, as do parts of the southwestern flow ( 30 km SSE of Paksong). ${ }^{40} \mathrm{Ar}-{ }^{39} \mathrm{Ar}$ dates thus far on both of the SW and W flow have not been successful, due to lack or scarcity of radiogenic argon. Dating of a small flow near Pakse and another flow in the northern flow complex ( $20 \mathrm{~km} \mathrm{SW}$ of Salavan) were also unsuccessful and for the same reason. The implication is that all four of these flow complexes are likely very young (the ${ }^{40} \mathrm{Ar}-{ }^{39} \mathrm{Ar}$ dating method becomes less reliable with decreasing age; Hill et al., 1993). The flow in the northern flow complex, in particular, shows a very little developed soil compared to nearby flows dated $\sim 100 \mathrm{ka}$. This field analysis also supports our ARI estimate of $\sim 10,000$ years or less. The 
radiocarbon dating method would offer a better solution for flows younger than 40 ka on the BVF, however, organic matter is unlikely to be preserved in basaltic lava flows, where temperature exceeds $1000^{\circ} \mathrm{C}$, and has not been found in any of the flows, nor in any paleosol between them. Further geological studies would be valuable to map and date the flows across the BVF in more detail and provide a more precise ARI.

\section{Conclusions}

We conducted the first volcanic hazard and exposure assessment of a volcanic field in northern SE Asia, using field and geochronological data, remote sensing and numerical modelling. We find that future eruptions of lava in the BVF may have socio-economic impacts on the local population and their activities. Inundations of cities and villages, roads, power lines, dams, and coffee plantations are possible but have low likelihood relative to more active volcanic arcs in southern SE Asia. The abundance of groundwater in the weathered and permeable lavas of the plateau mean that explosive phreatomagmatic activity is also plausible and may be more hazardous than lava flows. The maximum average recurrence interval of the BVF is $\leq 10,400$ years, much shorter than the time since the $34 \mathrm{ka}$ date of the most recent Ar-Ar-dated eruption. This initial study of the BVF provides the tools and emphasizes the necessity of investigating other understudied volcanic fields in the region, in order to improve awareness of and preparedness for future volcanic crises.

\section{Availability of data and material}

Additional data are presented in the Supplementary material file.

\section{Authors contributions:}

AV: manuscript preparation, figures production, data elaboration, analysis and interpretation, editing. SJ: lava flow simulations, editing. KS: field data collection, editing. JH: field data collection, editing. DSA: field data collection, editing. VS: fieldwork support. JHO: contribution to remote sensing mapping

\section{Competing interests}

No applicable 
This research was supported by the Earth Observatory of Singapore via its funding from the National Research Foundation Singapore and the Singapore Ministry of Education under the Research Centers of Excellence initiative. This work comprises EOS contribution number 404.

\section{Acknowledgments}

\section{References}

We thank reviewers and editor for their effort in reviewing this manuscript. We also would like to thank Tobias Dürig for insightful discussions about phreatomagmatic eruptions and Benoit Taisne for discussions about dikes dynamics.

Ainsworth, A., Kauffman, J.B., 2009. Response of native Hawaiian woody species to lava-ignited wildfires in tropical forests and shrublands. Plant Ecol 201, 197-209. https://doi.org/10.1007/s11258-008-9538-3

Applegate, E., 2016. Detection of peri-urban and agricultural expansion 1990-2015 in Pakse, Laos, using dense time stacks of landsat imagery. University of Wisconsin-Madison.

Barr, S.M., Macdonald, A.S., 1981. Geochemistry and Geochronology of Late Cenozoic Basalts of Southeast Asia. GSA Bulletin 92, 1069-1142. https://doi.org/10.1130/GSAB-P2-92-1069

Barsotti, S., Di Rienzo, D.I., Thordarson, T., Björnsson, B.B., Karlsdóttir, S., 2018. Assessing Impact to Infrastructures Due to Tephra Fallout From Öræfajökull Volcano (Iceland) by Using a ScenarioBased Approach and a Numerical Model. Front. Earth Sci. 6, 196. https://doi.org/10.3389/feart.2018.00196

Bartolini, S., Cappello, A., Martí, J., Del Negro, C., 2013. QVAST: a new Quantum GIS plugin for estimating volcanic susceptibility. Nat. Hazards Earth Syst. Sci. 13, 3031-3042. https://doi.org/10.5194/nhess-13-3031-2013

Baxter, P., Allard, P., Halbwachs, M., Komorowski, J.C., Woods, A., Ancia, A., 2002. Human health and vulnerability in the Nyiragongo volcano eruption and humanitarian crisis at Goma, Democratic Republic of Congo. Acta Vulcanol. 2002;14-15(1-2):109-14.

Becerril, L., Bartolini, S., Sobradelo, R., Martí, J., Morales, J.M., Galindo, I., 2014. Long-term volcanic hazard assessment on El Hierro (Canary Islands). Nat. Hazards Earth Syst. Sci. 14, 1853-1870. https://doi.org/10.5194/nhess-14-1853-2014

Belousov, A., Behncke, B., Belousova, M., 2011. Generation of pyroclastic flows by explosive interaction of lava flows with ice/water-saturated substrate. Journal of Volcanology and Geothermal Research 202, 60-72. https://doi.org/10.1016/j.jvolgeores.2011.01.004

Belousov, A., Belousova, M., Edwards, B., Volynets, A., Melnikov, D., 2015. Overview of the precursors and dynamics of the 2012-13 basaltic fissure eruption of Tolbachik Volcano, Kamchatka, Russia. Journal of Volcanology and Geothermal Research 307, 22-37. https://doi.org/10.1016/j.jvolgeores.2015.06.013

Bevilacqua, A., Isaia, R., Neri, A., Vitale, S., Aspinall, W.P., Bisson, M., Flandoli, F., Baxter, P.J., Bertagnini, A., Esposti Ongaro, T., lannuzzi, E., Pistolesi, M., Rosi, M., 2015. Quantifying volcanic hazard at Campi Flegrei caldera (Italy) with uncertainty assessment: 1. Vent opening maps: VENT OPENING MAPS AT CAMPI FLEGREI. J. Geophys. Res. Solid Earth 120, 2309-2329. https://doi.org/10.1002/2014JB011775

Bisson, M., Behncke, B., Fornaciai, A., Neri, M., 2009. LiDAR-based digital terrain analysis of an area exposed to the risk of lava flow invasion: the Zafferana Etnea territory, Mt. Etna (Italy). Nat Hazards 50, 321-334. https://doi.org/10.1007/s11069-009-9346-7

Bondarenko, M., Kerr, D., Sorichetta, A., Tatem, A., 2020. Census/projection-disaggregated gridded population datasets, adjusted to match the corresponding UNPD 2020 estimates, for 183 
countries in 2020 using Built-Settlement Growth Model (BSGM) outputs. https://doi.org/10.5258/SOTON/WP00685

Bonne, K., Kervyn, M., Cascone, L., Njome, S., Ranst, E.V., Suh, E., Ayonghe, S., Jacobs, P., Ernst, G., 2008. A new approach to assess long-term lava flow hazard and risk using GIS and low-cost remote sensing: the case of Mount Cameroon, West Africa. International Journal of Remote Sensing 29, 6539-6564. https://doi.org/10.1080/01431160802167873

Boreham, F., Cashman, K., Rust, A., 2020. Hazards from lava-river interactions during the 1783-1784 Laki fissure eruption. GSA Bulletin 132, 2651-2668. https://doi.org/10.1130/B35183.1

Brown, C.G., Sarabandi, K., Pierce, L.E., 2005. Validation of the Shuttle Radar Topography Mission height data. IEEE Trans. Geosci. Remote Sensing 43, 1707-1715. https://doi.org/10.1109/TGRS.2005.851789

Brown, S.K., Jenkins, S.F., Sparks, R.S.J., Odbert, H., Auker, M.R., 2017. Volcanic fatalities database: analysis of volcanic threat with distance and victim classification. J Appl. Volcanol. 6, 15. https://doi.org/10.1186/s13617-017-0067-4

Calka, B., Bielecka, E., 2019. Reliability Analysis of LandScan Gridded Population Data. The Case Study of Poland. IJGI 8, 222. https://doi.org/10.3390/ijgi8050222

Cappello, A., Neri, M., Acocella, V., Gallo, G., Vicari, A., Del Negro, C., 2012. Spatial vent opening probability map of Etna volcano (Sicily, Italy). Bull Volcanol 74, 2083-2094. https://doi.org/10.1007/s00445-012-0647-4

Cappello, A., Vicari, A., Del Negro, C., 2011. Assessment and Modeling of Lava Flow Hazard on Mt. Etna Volcano. BGTA. https://doi.org/10.4430/bgta0003

Capra, L., Manea, V.C., Manea, M., Norini, G., 2011. The importance of digital elevation model resolution on granular flow simulations: a test case for Colima volcano using TITAN2D computational routine. Nat Hazards 59, 665-680. https://doi.org/10.1007/s11069-011-97886

CGLS-LC100, 2019. Copernicus Global Land Service. https://land.copernicus.eu/global/viewing.

Colkesen, I., Sahin, E.K., Kavzoglu, T., 2016. Susceptibility mapping of shallow landslides using kernelbased Gaussian process, support vector machines and logistic regression. Journal of African Earth Sciences 118, 53-64. https://doi.org/10.1016/j.jafrearsci.2016.02.019

Connor, C.B., Connor, L., Germa, A., Richardson, J., Bebbington, M., Gallant, E., Saballos, A., 2019. How to use kernel density estimation as a diagnostic and forecasting tool for distributed volcanic vents. SIV 4, 1-25. https://doi.org/10.5038/2163-338X.4.3

Connor, L.J., Connor, C.B., Meliksetian, K., Savov, I., 2012. Probabilistic approach to modeling lava flow inundation: a lava flow hazard assessment for a nuclear facility in Armenia. J Appl. Volcanol. 1, 3. https://doi.org/10.1186/2191-5040-1-3

Delang, C.O., Toro, M., 2011. Hydropower-Induced Displacement and Resettlement in the Lao PDR. South East Asia Research 19, 567-594. https://doi.org/10.5367/sear.2011.0056

Delang, C.O., Toro, M., Charlet-Phommachanh, M., 2013. Coffee, mines and dams: conflicts over land in the Bolaven Plateau, southern Lao PDR: Coffee, mines and dams. The Geographical Journal 179, 150-164. https://doi.org/10.1111/j.1475-4959.2012.00481.x

Deligne, N.I., Fitzgerald, R.H., Blake, D.M., Davies, A.J., Hayes, J.L., Stewart, C., Wilson, G., Wilson, T.M., Castelino, R., Kennedy, B.M., Muspratt, S., Woods, R., 2017. Investigating the consequences of urban volcanism using a scenario approach I: Development and application of a hypothetical eruption in the Auckland Volcanic Field, New Zealand. Journal of Volcanology and Geothermal Research 336, 192-208. https://doi.org/10.1016/j.jvolgeores.2017.02.023

Deng, F., Rodgers, M., Xie, S., Dixon, T.H., Charbonnier, S., Gallant, E.A., López Vélez, C.M., Ordoñez, M., Malservisi, R., Voss, N.K., Richardson, J.A., 2019. High-resolution DEM generation from spaceborne and terrestrial remote sensing data for improved volcano hazard assessment A case study at Nevado del Ruiz, Colombia. Remote Sensing of Environment 233, 111348. https://doi.org/10.1016/j.rse.2019.111348 
Department of Energy Policy and Planning, Ministry of Energy and Mines, 2020. Lao PDR Energy Outlook 2020.

Dürig, T., White, J.D.L., Murch, A.P., Zimanowski, B., Büttner, R., Mele, D., Dellino, P., Carey, R.J., Schmidt, L.S., Spitznagel, N., 2020a. Deep-sea eruptions boosted by induced fuel-coolant explosions. Nat. Geosci. 13, 498-503. https://doi.org/10.1038/s41561-020-0603-4

Dürig, T., White, J.D.L., Zimanowski, B., Büttner, R., Murch, A., Carey, R.J., 2020b. Deep-sea fragmentation style of Havre revealed by dendrogrammatic analyses of particle morphometry. Bull Volcanol 82, 67. https://doi.org/10.1007/s00445-020-01408-1

Fagents, S.A., Thordarson, T., 2007. Rootless volcanic cones in Iceland and on Mars. The geology of Mars: Evidence from Earth-based analogs, 151-177.

Favalli, M., 2005. Forecasting lava flow paths by a stochastic approach. Geophys. Res. Lett. 32, L03305. https://doi.org/10.1029/2004GL021718

Felpeto, A., Martí, J., Ortiz, R., 2007. Automatic GIS-based system for volcanic hazard assessment. Journal of Volcanology and Geothermal Research 166, 106-116. https://doi.org/10.1016/j.jvolgeores.2007.07.008

Fitch, E.P., Fagents, S.A., 2020. Characteristics of rootless cone tephra emplaced by high-energy lavawater explosions. Bull Volcanol 82, 62. https://doi.org/10.1007/s00445-020-01393-5

Folco, L., D’Orazio, M., Gemelli, M., Rochette, P., 2016. Stretching out the Australasian microtektite strewn field in Victoria Land Transantarctic Mountains. Polar Science 10, 147-159. https://doi.org/10.1016/j.polar.2016.02.004

Freire, S., Doxsey-Whitfield, E., MacManus, K., Mills, J., Pesaresi, M., 2016. Development of new open and free multi-temporal global population grids at $250 \mathrm{~m}$ resolution 7.

Freire, S., Florczyk, A., Pesaresi, M., Sliuzas, R., 2019. An Improved Global Analysis of Population Distribution in Proximity to Active Volcanoes, 1975-2015. IJGI 8, 341. https://doi.org/10.3390/ijgi8080341

Gallant, E., Richardson, J., Connor, C., Wetmore, P., Connor, L., 2018. A new approach to probabilistic lava flow hazard assessments, applied to the Idaho National Laboratory, eastern Snake River Plain, Idaho, USA. Geology 46, 895-898. https://doi.org/10.1130/G45123.1

Global Volcanism Program, 2013. Global Volcanism Program, 2013. Bolaven Plateau, v. 4.10.0 (19 June 2021). Venzke, E (ed.). Smithsonian Institution. Downloaded 19 Jun 2021. https://volcano.si.edu/volcano.cfm?vn=275813.

Hackett, W.R., Morgan, L.A., 1988. Explosive basaltic and rhyolitic volcanism of the Eastern Snake River Plain, Idaho. Idaho Geological Survey Bulletin 27:283-301.

Hamilton, C.W., Thordarson, T., Fagents, S.A., 2010. Explosive lava-water interactions I: architecture and emplacement chronology of volcanic rootless cone groups in the 1783-1784 Laki lava flow, Iceland. Bull Volcanol 72, 449-467. https://doi.org/10.1007/s00445-009-0330-6

Hamilton, W.H., Myers, W.B., 1963. Menan Buttes, cones of glassy basalt tuff in the Snake River Plain, Idaho. United States Geological Survey Professional Paper 450-E:114-118.

Harris, A.J.L., 2015. Basaltic Lava Flow Hazard, in: Volcanic Hazards, Risks and Disasters. Elsevier, pp. 17-46. https://doi.org/10.1016/B978-0-12-396453-3.00002-2

Hayes, J.L., Wilson, T.M., Brown, C., Deligne, N.I., Leonard, G.S., Cole, J., 2021. Assessing urban disaster waste management requirements after volcanic eruptions. International Journal of Disaster Risk Reduction 52, 101935. https://doi.org/10.1016/j.ijdrr.2020.101935

Heaney, L.R., 1991. A synopsis of climatic and vegetational change in Southeast Asia. In Tropical Forests and Climate (pp. 53-61). Springer, Dordrecht.

Herrin, J., Schonwalder, D., Sieh, K., Jicha, B., Singer, B., Wiwegwin, W., Verolino, A., In prep. The 16million-year history of the Bolaven Volcanic Field, Laos. In preparation for Geological Society of America Bulletin.

Hill, B., Leslie, B., Connor, C., 1993. A Review and Analysis of Dating Techniques for Neogene and Quaternary Volcanic Rocks. Nuclear Regulatory Commission Contract NRC-02-88-005. 
Japan International Cooperation Agency, 2015. Natural Disaster Risk Assessment and Area Business Continuity Plan Formulation for Industrial Agglomerated Areas in the ASEAN Region.

Japan International Cooperation Agency, 2008. The Geological Mapping and Mineral Information Service Project for Promotion of Mining Industry in the Lao People's Democratic Republic Final Report Volume I: Summary October 2008.

Jenkins, S.F., Day, S.J., Faria, B.V.E., Fonseca, J.F.B.D., 2017. Damage from lava flows: insights from the 2014-2015 eruption of Fogo, Cape Verde. J Appl. Volcanol. 6, 6. https://doi.org/10.1186/s13617-017-0057-6

Jenkins, S.F., Wilson, T.M., Magill, C., Miller, V., Stewart, C., Blong, R., Marzocchi, W., Boulton, M., Bonadonna, C., Costa, A., 2015. Volcanic ash fall hazard and risk. Global volcanic hazards and risk, 173-222.

Jiménez, D., Becerril, L., Bartolini, S., Escobar, D., Martí, J., 2020. Making a qualitative volcanic-hazards map by combining simulated scenarios: An example for San Miguel Volcano (El Salvador). Journal of Volcanology and Geothermal Research 395, 106837. https://doi.org/10.1016/j.jvolgeores.2020.106837

Jiménez, D., Becerril, L., Carballo, A., Baires, S., Martí, J., 2019. Estimating exposure around San Miguel Volcano, El Salvador. Journal of Volcanology and Geothermal Research 386, 106675. https://doi.org/10.1016/j.jvolgeores.2019.106675

Jones, A.P., 2005. Meteorite Impacts as Triggers to Large Igneous Provinces. Elements 1, $277-281$. https://doi.org/10.2113/gselements.1.5.277

Kereszturi, G., Procter, J., Cronin, S.J., Németh, K., Bebbington, M., Lindsay, J., 2012. LiDAR-based quantification of lava flow susceptibility in the City of Auckland (New Zealand). Remote Sensing of Environment 125, 198-213. https://doi.org/10.1016/j.rse.2012.07.015

Kubanek, J., Richardson, J.A., Charbonnier, S.J., Connor, L.J., 2015. Lava flow mapping and volume calculations for the 2012-2013 Tolbachik, Kamchatka, fissure eruption using bistatic TanDEMX InSAR. Bull Volcanol 77, 106. https://doi.org/10.1007/s00445-015-0989-9

Latrubesse, E.M., Park, E., Sieh, K., Dang, T., Lin, Y.N., Yun, S.-H., 2020. Dam failure and a catastrophic flood in the Mekong basin (Bolaven Plateau), southern Laos, 2018. Geomorphology 362, 107221. https://doi.org/10.1016/j.geomorph.2020.107221

Long, Y., Yang, X., Yang, M., Zhang, D., 2019. Exploration and Sources of Bauxite Deposit in the Bolaven Plateau, Southern Laos. J. Earth Sci. 30, 121-130. https://doi.org/10.1007/s12583-019-08571

Lorenz, V., Haneke, J., 2004. Relationship between diatremes, dykes, sills, laccoliths, intrusiveextrusive domes, lava flows, and tephra deposits with unconsolidated water-saturated sediments in the late Variscan intermontane Saar-Nahe Basin, SW Germany. Geological Society, London, Special Publications 234, 75-124. https://doi.org/10.1144/GSL.SP.2004.234.01.07

Martin, A.J., Umeda, K., Connor, C.B., Weller, J.N., Zhao, D., Takahashi, M., 2004. Modeling long-term volcanic hazards through Bayesian inference: An example from the Tohoku volcanic arc, Japan: BAYESIAN INFERENCE OF VOLCANISM. J. Geophys. Res. 109. https://doi.org/10.1029/2004JB003201

Meredith, E.S., Jenkins, S.F., Hayes, J.L., Deligne, N.I., Lallemant, D., Patrick, M.P., Neal, C., in review. Damage assessment for the 2018 Lower East Rift Zone lava flows of Kīlauea volcano, Hawai'i.

Mishra, A.K., Placzek, C., Wurster, C., Whitehead, P.W., 2019. New radiocarbon age constraints for the $120 \mathrm{~km}$-long Toomba flow, north Queensland, Australia. Australian Journal of Earth Sciences 66, 71-79. https://doi.org/10.1080/08120099.2019.1523227

Mossoux, S., Saey, M., Bartolini, S., Poppe, S., Canters, F., Kervyn, M., 2016. Q-LAVHA: A flexible GIS plugin to simulate lava flows. Computers \& Geosciences 97, 98-109. https://doi.org/10.1016/j.cageo.2016.09.003

Muller, G., Veyl, G., 1956. The birth of Nilahue, a new maar type volcano at Rininahue, Chile. 20th International Geological Congress, Mexico, pp. 375-396. 
Murcia, H., Németh, K., Moufti, M.R., Lindsay, J.M., El-Masry, N., Cronin, S.J., Qaddah, A., Smith, I.E.M., 2014. Late Holocene lava flow morphotypes of northern Harrat Rahat, Kingdom of Saudi Arabia: Implications for the description of continental lava fields. Journal of Asian Earth Sciences 84, 131-145. https://doi.org/10.1016/i.jseaes.2013.10.002

Nakamura, K., 1977. Volcanoes as possible indicators of tectonic stress orientation - principle and proposal. Journal of Volcanology and Geothermal Research 2, 1-16. https://doi.org/10.1016/0377-0273(77)90012-9

Németh, K., Cronin, S.J., Charley, D.T., Harrison, M.J., Garae, E., 2006. Exploding lakes in Vanuatu"Surtseyan-style" eruptions witnessed on Ambae Island. Massey University. Episodes 29. http://hdl.handle.net/10179/9629.

Nemeth, K., Suwesi, K.S., Peregi, Z., Gulácsi, Z., Ujszászi, J., 2003. Plio/Pleistocene flood basalt related scoria and spatter cones, rootless lava flows, and pit craters, A1 Haruj A1 Abyad, Libya. Geolines 15, 98-103.

Nomikou, P., Carey, S., Bell, K.L.C., Papanikolaou, D., Bejelou, K., Cantner, K., Sakellariou, D., Perros, I., 2014. Tsunami hazard risk of a future volcanic eruption of Kolumbo submarine volcano, NE of Santorini Caldera, Greece. Nat Hazards 72, 1375-1390. https://doi.org/10.1007/s11069-0120405-0

Open Development Laos, 2016. Greater Mekong Subregion hydropower dams (2016). https://data.laos.opendevelopmentmekong.net/dataset/greater-mekong-subregionhydropower-dams-2016.

OpenStreetMap Foundation (OSMF) \& Contributors, 2016. OpenStreetMap (OSM) January. Planet OSM http://planet.openstreetmap. org/; http://www.openstreetmap.org; http://www.opendatacommons.org; http://www.creativecommons.org.

Orsi, G., Di Vito, M.A., Isaia, R., 2004. Volcanic hazard assessment at the restless Campi Flegrei caldera. Bull Volcanol 66, 514-530. https://doi.org/10.1007/s00445-003-0336-4

Pailoplee, S., Charusiri, P., 2017. Analyses of seismic activities and hazards in Laos: A seismicity approach. Terr. Atmos. Ocean. Sci. 28, 843-853. https://doi.org/10.3319/TA0.2017.03.23.01

Pansino, S., Emadzadeh, A., Taisne, B., 2019. Dike Channelization and Solidification: Time Scale Controls on the Geometry and Placement of Magma Migration Pathways. J. Geophys. Res. Solid Earth 124, 9580-9599. https://doi.org/10.1029/2019JB018191

Pedersen, G.B.M., Höskuldsson, A., Dürig, T., Thordarson, T., Jónsdóttir, I., Riishuus, M.S., Óskarsson, B.V., Dumont, S., Magnusson, E., Gudmundsson, M.T., Sigmundsson, F., Drouin, V.J.P.B., Gallagher, C., Askew, R., Gudnason, J., Moreland, W.M., Nikkola, P., Reynolds, H.I., Schmith, J., 2017. Lava field evolution and emplacement dynamics of the 2014-2015 basaltic fissure eruption at Holuhraun, Iceland. Journal of Volcanology and Geothermal Research 340, 155169. https://doi.org/10.1016/j.jvolgeores.2017.02.027

Phommakaysone, K., 2012. The geology and mineral resources of Lao PDR.

Pink, R.M., 2016. Laos: The Poorest Country in Asia, in: Water Rights in Southeast Asia and India. Palgrave Macmillan US, New York, pp. 119-138. https://doi.org/10.1057/9781137504234_6

Ramanna, C.K., Dodagoudar, G.R., 2012. Seismic Hazard Analysis Using the Adaptive Kernel Density Estimation Technique for Chennai City. Pure Appl. Geophys. 169, 55-69. https://doi.org/10.1007/s00024-011-0264-8

Richter, N., Favalli, M., de Zeeuw-van Dalfsen, E., Fornaciai, A., da Silva Fernandes, R.M., Pérez, N.M., Levy, J., Victória, S.S., Walter, T.R., 2016. Lava flow hazard at Fogo Volcano, Cabo Verde, before and after the 2014-2015eruption. Nat. Hazards Earth Syst. Sci. 16, 1925-1951. https://doi.org/10.5194/nhess-16-1925-2016

Rose, A.N., McKee, J.J., Sims, K.M., Bright, E.A., Reith, A.E., Urban, M.L., 2019. LandScan 2019. Oak Ridge National Laboratory.

Runge, M.G., Bebbington, M.S., Cronin, S.J., Lindsay, J.M., Kenedi, C.L., Moufti, M.R.H., 2014. Vents to events: determining an eruption event record from volcanic vent structures for the Harrat Rahat, Saudi Arabia. Bull Volcanol 76, 804. https://doi.org/10.1007/s00445-014-0804-z 
Sandri, L., Jolly, G., Lindsay, J., Howe, T., Marzocchi, W., 2012. Combining long- and short-term probabilistic volcanic hazard assessment with cost-benefit analysis to support decision making in a volcanic crisis from the Auckland Volcanic Field, New Zealand. Bull Volcanol 74, 705-723. https://doi.org/10.1007/s00445-011-0556-y

Sanematsu, K., Moriyama, T., Sotouky, L., Watanabe, Y., 2011. Mobility of Rare Earth Elements in Basalt-Derived Laterite at the Bolaven Plateau, Southern Laos: Mobility of rare earth elements in laterite. Resource Geology 61, 140-158. https://doi.org/10.1111/j.17513928.2011.00155.x

Schiavina, M., Freire, S., MacManus, K., 2019. GHS population grid multitemporal (1975, 1990, 2000, 2015) R2019A. European Commission, Joint Research Center (JRC). https://doi.org/10.2905/42E8BE89-54FF-464E-BE7B-BF9E64DA5218

Schipper, C.I., White, J.D.L., Zimanowski, B., Büttner, R., Sonder, I., Schmid, A., 2011. Experimental interaction of magma and "dirty" coolants. Earth and Planetary Science Letters 303, 323-336. https://doi.org/10.1016/j.epsl.2011.01.010

Sieh, K., Herrin, J., Jicha, B., Schonwalder Angel, D., Moore, J.D.P., Banerjee, P., Wiwegwin, W., Sihavong, V., Singer, B., Chualaowanich, T., Charusiri, P., 2019. Australasian impact crater buried under the Bolaven volcanic field, Southern Laos. Proc Natl Acad Sci USA 117, 13461353. https://doi.org/10.1073/pnas.1904368116

Silverman, B.W., 1998. Density estimation for statistics and data analysis, Monographs on statistics and applied probability. Chapman \& Hall/CRC, Boca Raton.

Small, C., Pozzi, F., Elvidge, C., 2005. Spatial analysis of global urban extent from DMSP-OLS night lights. Remote Sensing of Environment 96, 277-291. https://doi.org/10.1016/j.rse.2005.02.002

Thorarinsson, S., 1964. Surtsey, the new island in the North Atlantic. Reykjavik: Almenna Bokofelagid. Toro, M., 2012. Coffee Markets, Smallholder Credit, and Landscape Change in the Bolaven Plateau Region, Laos (Doctoral dissertation, University of Miami).

Tsang, S.W.R., Lindsay, J.M., 2020. Lava flow crises in inhabited areas part I: lessons learned and research gaps related to effusive, basaltic eruptions. J Appl. Volcanol. 9, 9. https://doi.org/10.1186/s13617-020-00096-y

Tsang, S.W.R., Lindsay, J.M., Coco, G., Deligne, N.I., 2020. The influence of surficial features in lava flow modelling. J Appl. Volcanol. 9, 6. https://doi.org/10.1186/s13617-020-00095-z

Tulet, J.C., 2007. Development Trends Analysis on the Bolaven Plateau. Pakxe: Ministry of Agriculture and Forestry, Programme of Capitalisation in Support of Rural Development Policy (PCADR) Boloven Application Point (PAB), French Development Agency.

Valentine, G.A., White, J.D.L., 2012. Revised conceptual model for maar-diatremes: Subsurface processes, energetics, and eruptive products. Geology 40, 1111-1114. https://doi.org/10.1130/G33411.1

Vassilopoulou, S., Hurni, L., Dietrich, V., Baltsavias, E., Pateraki, M., Lagios, E., Parcharidis, I., 2002. Orthophoto generation using IKONOS imagery and high-resolution DEM: a case study on volcanic hazard monitoring of Nisyros Island (Greece). ISPRS Journal of Photogrammetry and Remote Sensing 57, 24-38. https://doi.org/10.1016/S0924-2716(02)00126-0

Vaughan, R.G., Webley, P.W., 2010. Satellite observations of a surtseyan eruption: Hunga Ha'apai, Tonga. Journal of Volcanology and Geothermal Research 198, 177-186. https://doi.org/10.1016/j.jvolgeores.2010.08.017

Verolino, A., White, J.D.L., Brenna, M., 2018. Eruption dynamics at Pahvant Butte volcano, Utah, western USA: insights from ash-sheet dispersal, grain size, and geochemical data. Bull Volcanol 80, 81. https://doi.org/10.1007/s00445-018-1256-7

Verolino, A., White, J.D.L., Dürig, T., Cappuccio, F., 2019. Black Point - Pyroclasts of a Surtseyan eruption show no change during edifice growth to the surface from $100 \mathrm{~m}$ water depth. Journal of Volcanology and Geothermal Research 384, 85-102. https://doi.org/10.1016/j.jvolgeores.2019.07.013 
Viossanges, Paul Pavelic, Lisa-Maria Rebelo, Guillaume Lacombe, Touleelor Sotoukee, 2017. Regional Mapping of Groundwater Resources in Data-Scarce Regions: The Case of Laos. Hydrology 5, 2. https://doi.org/10.3390/hydrology5010002

Wardrop, N.A., Jochem, W.C., Bird, T.J., Chamberlain, H.R., Clarke, D., Kerr, D., Bengtsson, L., Juran, S., Seaman, V., Tatem, A.J., 2018. Spatially disaggregated population estimates in the absence of national population and housing census data. Proc Natl Acad Sci USA 115, 3529-3537. https://doi.org/10.1073/pnas.1715305115

Waters, A.C., Fisher, R.V., 1971. Base surges and their deposits: Capelinhos and Taal Volcanoes. J. Geophys. Res. 76, 5596-5614. https://doi.org/10.1029/JB076i023p05596

Whitford-Stark, J.L., 1987. A survey of Cenozoic volcanism on mainland Asia, Special paper / the Geological Society of America. Geological Society of America, Boulder, Colo.

Williams, R.S., Moore, J.G., 1983. Man Against Volcano: The Eruption on Heimaey. Vestmannaeyjar, Iceland. United States Geological Survey Open File Report. https://pubs.usgs.gov/gip/heimaey/heimaey.pdf.

Wohletz, K.H., Zimanowski, B., Büttner, R., 2013. Magma-water interactions, in: Fagents, S.A., Gregg, T.K.P., Lopes, R.M.C. (Eds.), Modeling Volcanic Processes: The Physics and Mathematics of Volcanism. Cambridge University Press, Cambridge, pp. 230-257.

World Bank, 2019. World Development Indicators. Share of economic sectors in GDP in Laos 2019. https://www.statista.com/statistics/804979/share-of-economic-sectors-in-the-gdp-in-laos/.

Zhang, J., Xu, W., Qin, L., Tian, Y., 2018. Spatial Distribution Estimates of the Urban Population Using DSM and DEM Data in China. IJGI 7, 435. https://doi.org/10.3390/ijgi7110435

Zimanowski, B., Wohletz, K.H., 2000. Physics of phreatomagmatism I. Terra Nostra, 6(515), 23. 


\section{Supplementary Files}

This is a list of supplementary files associated with this preprint. Click to download.

- SupplementarymaterialAV.pdf 